Prepared in cooperation with the U.S. Department of the Interior Bureau of Reclamation and Bureau of Land Management

\title{
Development of a Regionally Consistent Geospatial Dataset of Agricultural Lands in the Upper Colorado River Basin, 2007-10
}

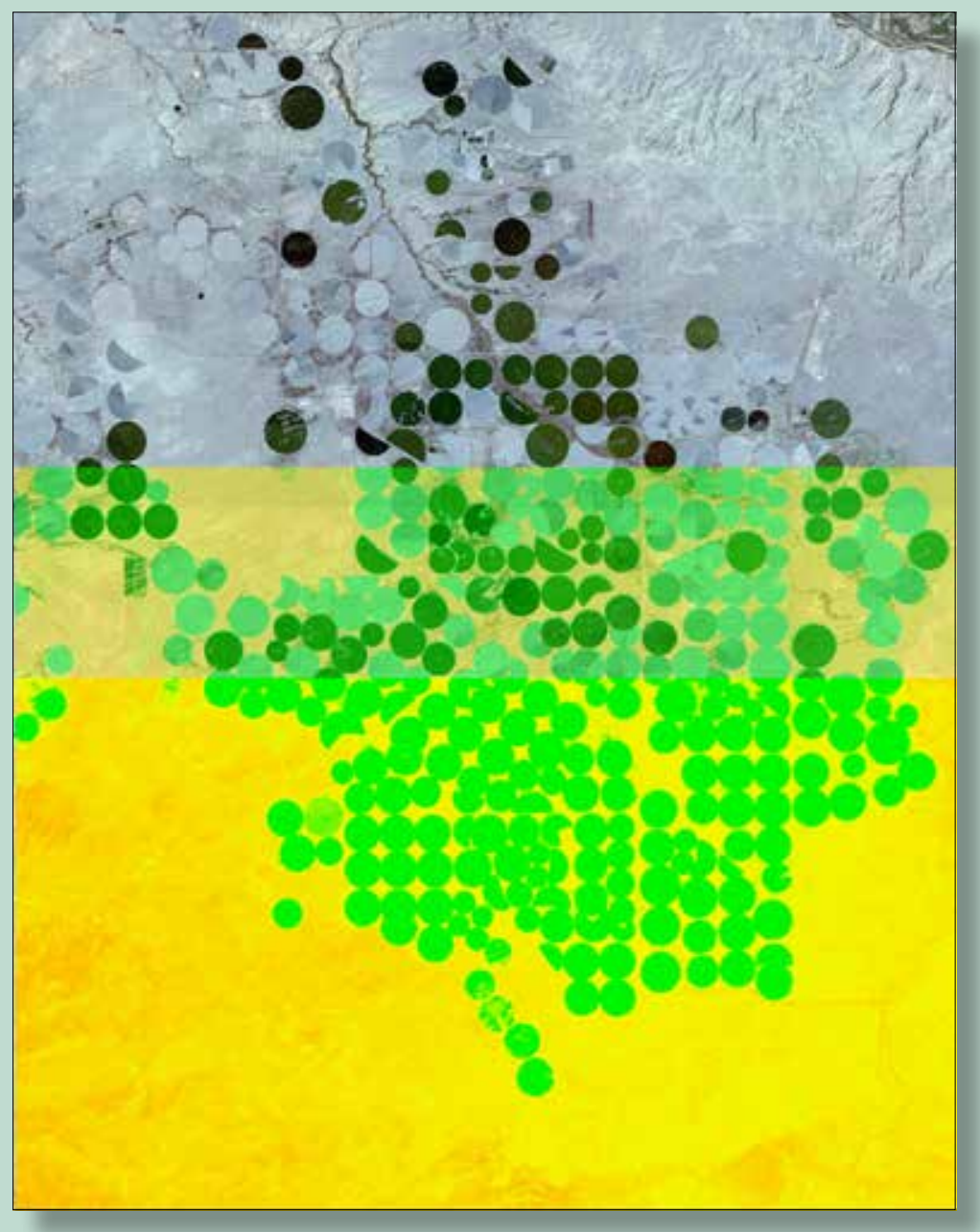

Scientific Investigations Report 2014-5039 
Cover image: 2011 National Agricultural Imagery Program image of center pivot irrigation in northwestern New Mexico overlain by Normalized Difference Vegetation Index (NDVI) image derived by selecting the maximum NDVI value from six Landsat 5 Thematic Mapper images 2007-10. 


\section{Development of a Regionally Consistent Geospatial Dataset of Agricultural Lands in the Upper Colorado River Basin, 2007-10}

By Susan G. Buto, Brittany L. Gold, and Kimberly A. Jones

Prepared in cooperation with the U.S. Department of the Interior Bureau of

Reclamation and Bureau of Land Management

Scientific Investigations Report 2014-5039 


\title{
U.S. Department of the Interior SALLY JEWELL, Secretary
}

\section{U.S. Geological Survey \\ Suzette M. Kimball, Acting Director}

\author{
U.S. Geological Survey, Reston, Virginia: 2014
}

For more information on the USGS - the Federal source for science about the Earth, its natural and living resources, natural hazards, and the environment, visit http://www.usgs.gov or call 1-888-ASK-USGS.

For an overview of USGS information products, including maps, imagery, and publications, visit http://Www.usgs.gov/pubprod.

To order this and other USGS information products, visit http://store.usgs.gov.

Any use of trade, firm, or product names is for descriptive purposes only and does not imply endorsement by the U.S. Government.

Although this information product, for the most part, is in the public domain, it also may contain copyrighted materials as noted in the text. Permission to reproduce copyrighted items must be secured from the copyright owner.

Suggested citation:

Buto, S.G., Gold, B.L., and Jones, K.A., 2014, Development of a regionally consistent geospatial dataset of agricultural lands in the Upper Colorado River Basin, 2007-10: U.S. Geological Survey Scientific Investigations Report 2014-5039, 20 p., http://dx.doi.org/10.3133/sir20145039.

ISSN 2328-0328 


\section{Contents}

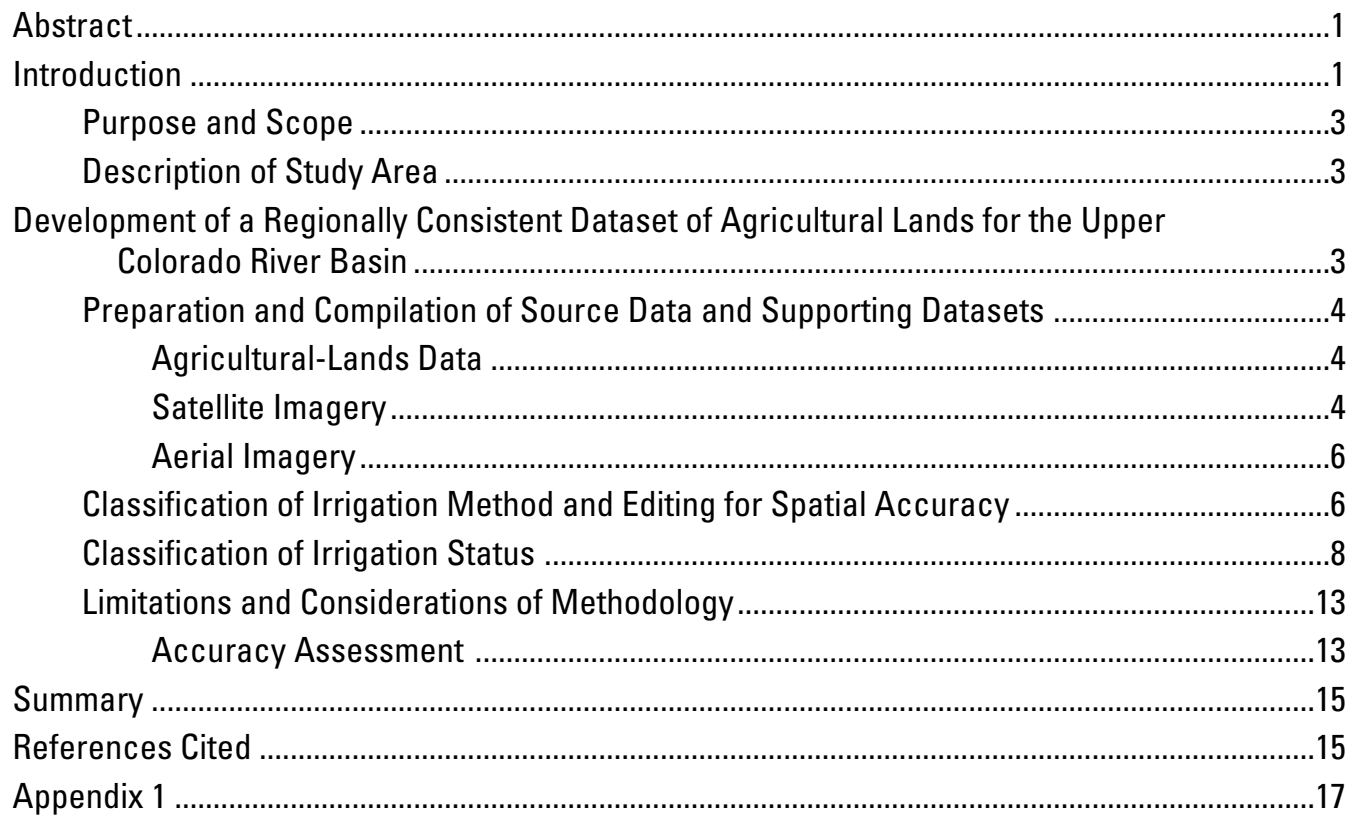

\section{Figures}

1. Mapped agricultural lands in the Upper Colorado River Basin study area ..............................2

2. Map showing World Reference System 2 path and row scene boundaries covering the extent of the Upper Colorado River Basin study area ............................................................

3. Maps showing $A$, Modified World Reference System 2 scene boundaries and polygon cells used to manage dataset review; and $B$, agricultural field polygons before editing; and $C$, after editing in part of the Upper Colorado River Basin study area

4. National Agricultural Imagery Program images showing examples of image interpretation techniques used to determine irrigation method used for $A$, center pivot irrigation; $B$, lateral or wheel line irrigation; $C$, center pivot and wheel line irrigation; and $D$, flood irrigation

5. Map showing agricultural lands in the Upper Colorado River Basin 2007-10 showing fields classified as irrigated and not irrigated and the method used to irrigate the field ..12

\section{Tables}

1. Sources of data used to develop the Upper Colorado River Basin dataset of agricultural lands ..3

2. Summary of irrigation status and method by state for the Upper Colorado River Basin, 2007-10

3. Assessment of the accuracy of irrigation method classification ........................................14

4. Assessment of automated and manual irrigation status classifications ...............................15

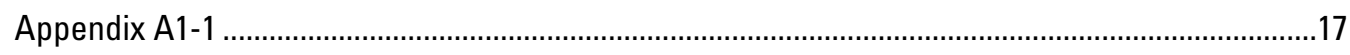

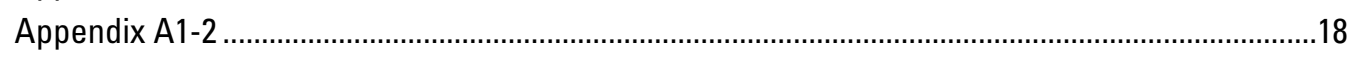

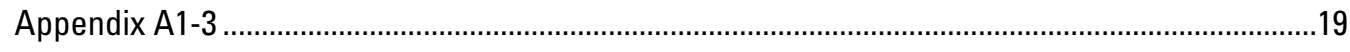

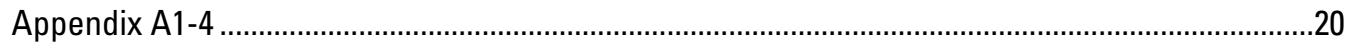




\section{Conversion Factors and Datums}

Inch/Pound to SI

\begin{tabular}{|c|c|c|}
\hline Multiply & By & To obtain \\
\hline \multicolumn{3}{|c|}{ Length } \\
\hline inch (in.) & 2.54 & centimeter $(\mathrm{cm})$ \\
\hline inch (in.) & 25.4 & millimeter (mm) \\
\hline inch (in.) & 25400 & micrometer $(\mu \mathrm{m})$ \\
\hline foot $(\mathrm{ft})$ & 0.3048 & meter $(\mathrm{m})$ \\
\hline mile (mi) & 1.609 & kilometer $(\mathrm{km})$ \\
\hline \multicolumn{3}{|c|}{ Area } \\
\hline acre & 4,047 & square meter $\left(\mathrm{m}^{2}\right)$ \\
\hline acre & 0.4047 & hectare (ha) \\
\hline square mile $\left(\mathrm{mi}^{2}\right)$ & 259.0 & hectare (ha) \\
\hline square mile $\left(\mathrm{mi}^{2}\right)$ & 2.590 & square kilometer $\left(\mathrm{km}^{2}\right)$ \\
\hline \multicolumn{3}{|c|}{ Volume } \\
\hline million gallons (Mgal) & 3,785 & cubic meter $\left(\mathrm{m}^{3}\right)$ \\
\hline \multicolumn{3}{|c|}{ Flow rate } \\
\hline million gallons per day (Mgal/d) & 0.04381 & cubic meter per second $\left(\mathrm{m}^{3} / \mathrm{s}\right)$ \\
\hline
\end{tabular}

SI to Inch/Pound

\begin{tabular}{lll}
\hline \multicolumn{1}{c}{ Multiply } & By & \multicolumn{1}{c}{ To obtain } \\
\hline micrometer $(\mu \mathrm{m})$ & Length & \\
meter $(\mathrm{m})$ & 0.00003937 & inch (in.) \\
& 3.281 & foot $(\mathrm{ft})$ \\
\hline square meter $\left(\mathrm{m}^{2}\right)$ & Area & \\
\hline
\end{tabular}

Horizontal coordinate information is referenced to the North American Datum of 1983 (NAD 83). 


\title{
Development of a Regionally Consistent Geospatial Dataset of Agricultural Lands in the Upper Colorado River Basin, 2007-10
}

\author{
By Susan G. Buto, Brittany L. Gold, and Kimberly A. Jones
}

\section{Abstract}

Irrigation in arid environments can alter the natural rate at which salts are dissolved and transported to streams. Irrigated agricultural lands are the major anthropogenic source of dissolved solids in the Upper Colorado River Basin (UCRB). Understanding the location, spatial distribution, and irrigation status of agricultural lands and the method used to deliver water to agricultural lands are important to help improve the understanding of agriculturally derived dissolved-solids loading to surface water in the UCRB. Irrigation status is the presence or absence of irrigation on an agricultural field during the selected growing season or seasons. Irrigation method is the system used to irrigate a field. Irrigation method can broadly be grouped into sprinkler or flood methods, although other techniques such as drip irrigation are used in the UCRB. Flood irrigation generally causes greater dissolved-solids loading to streams than sprinkler irrigation. Agricultural lands in the UCRB mapped by state agencies at varying spatial and temporal resolutions were assembled and edited to represent conditions in the UCRB between 2007 and 2010. Edits were based on examination of 1-meter resolution aerial imagery collected between 2009 and 2011. Remote sensing classification techniques were used to classify irrigation status for the June to September growing seasons between 2007 and 2010. The final dataset contains polygons representing approximately $1,759,900$ acres of agricultural lands in the UCRB. Approximately 66 percent of the mapped agricultural lands were likely irrigated during the study period.

\section{Introduction}

In arid regions of the world, natural rainfall is not sufficient to meet the water requirements for growing crops. In these regions, crops are irrigated by the application of water through a delivery system, such as sprinklers or pipes, to make up the difference between available rainfall and the water requirements of the crop. In 2005, the total volume of water used for irrigation in the United States was about 128,000 Mgal/d; the majority of the irrigation water used ( 85 percent) and irrigated acres ( 74 percent) was in the 17 conterminous Western States (Kenny and others, 2009). The Upper Colorado River Basin (UCRB) covers parts of five of those conterminous states: Arizona, Colorado, New Mexico, Utah, and Wyoming (fig. 1). Kenny and others (2009) estimate irrigation consumed approximately $27,900 \mathrm{Mgal} / \mathrm{d}$ to irrigate over 7,000,000 acres in the five UCRB states in 2005. Colorado used 44 percent of this water to irrigate 43 percent of the total estimated irrigated acres in 2005. Utah and Wyoming each used approximately 14 percent of the irrigation water to irrigate 17 and 14 percent of the total irrigated lands, respectively. Arizona and New Mexico used 17 and 10 percent of the irrigation water for 13 and 12 percent of the total agricultural land, respectively. Only a portion of the total area of irrigated agricultural lands in each state is in the UCRB.

Irrigation in arid environments can alter the natural rate at which salts are dissolved and transported to streams. Irrigated agricultural lands are the major anthropogenic source of dissolved solids in the UCRB (Iorns and others, 1965; Liebermann and others, 1989; U.S. Department of the Interior, 2003). Understanding the location, spatial distribution, and irrigation status of agricultural lands and the method used to deliver water to agricultural lands is important to help improve the understanding of agriculturally derived dissolved-solids loading to surface water in the UCRB. Irrigation status is the presence or absence of irrigation on an agricultural field during the selected growing season or seasons. Irrigation method is the system used to irrigate a field. Irrigation method can be broadly grouped into sprinkler or flood methods, although other techniques such as drip irrigation are used in the UCRB. Flood irrigation generally causes greater dissolved-solids loading to streams than sprinkler irrigation (Kenney and others, 2009).

Agricultural lands in the UCRB have been mapped at varying temporal and spatial resolutions by state and Federal agencies. Some of the mapped data are available for download from state-run websites or other sources. The data, in Geographic Information Systems (GIS) format, include agricultural field boundaries mapped at varying spatial resolution and precision using an assortment of techniques and information 


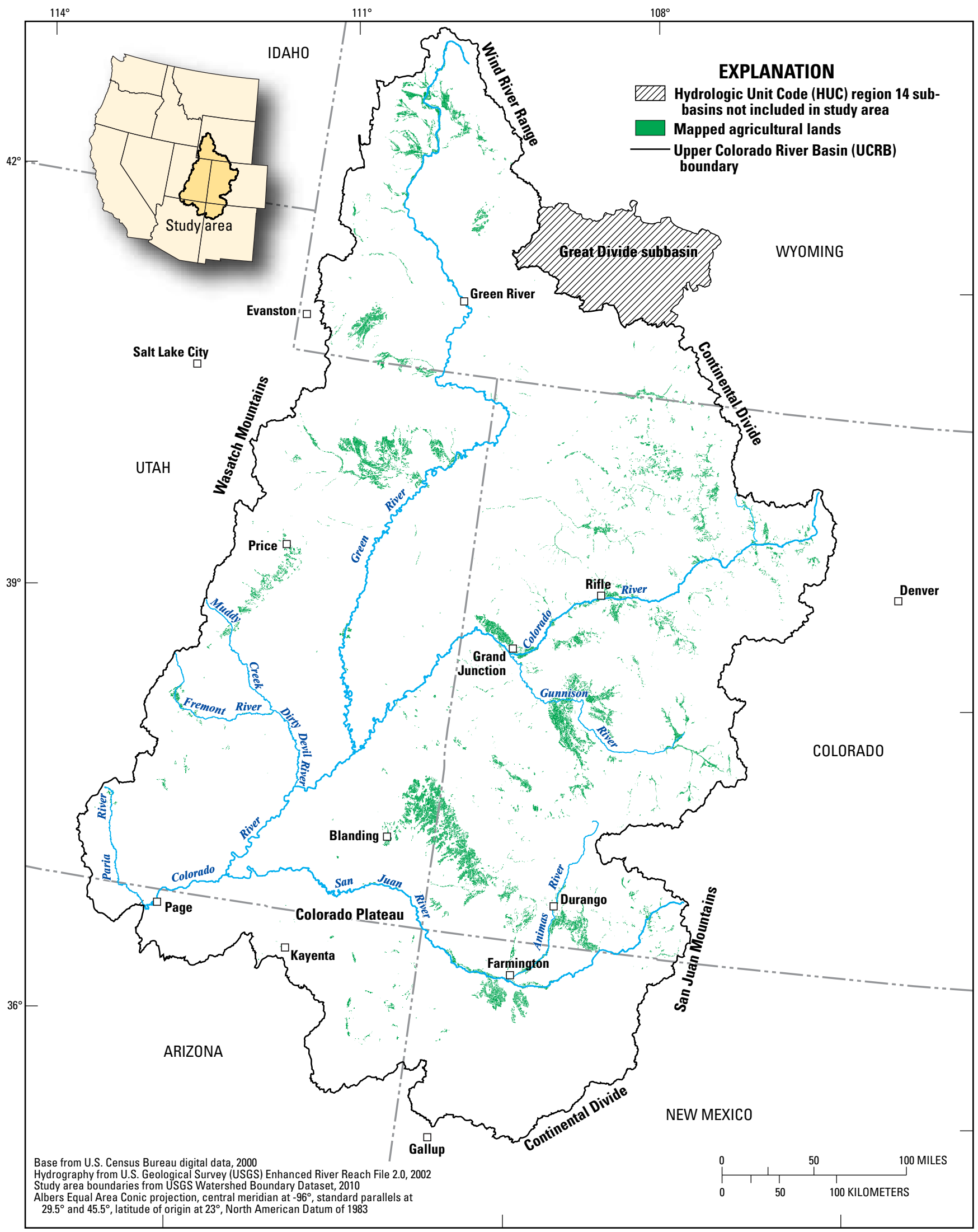

Figure 1. Mapped agricultural lands in the Upper Colorado River Basin study area. 
sources. Recent state mapping efforts include information about irrigation method, but the maps are from different time periods. For example, Utah data on agricultural lands, used as a source for this study, contain field boundaries mapped between 2001 and 2006. Data from Colorado include separate data layers representing conditions in 1993, 2001, and 2005.

Delineating accurate boundaries for agricultural lands, determining irrigation status of those lands, and further differentiating between land irrigated by flood and sprinkler methods are important to help refine existing dissolved-solids loading and transport models in the UCRB. Accurate maps of irrigated agriculture and irrigation practices can help focus and prioritize salinity control efforts by more precisely identifying areas where water quality may be impacted by irrigation and agricultural practices. In addition, consumptive water-use estimates in the basin rely on accurate maps of the location and extent of irrigated agriculture.

\section{Purpose and Scope}

This report documents the methods and data used to develop a spatially and temporally consistent regional GIS dataset of irrigated agriculture for the UCRB mapped at approximately 1:24,000 scale. The dataset represents average conditions in the summer growing season for the years 2007-10 and includes information about irrigation status and the type of irrigation used to deliver water to the land. For the purposes of this study, the growing season extends from June through September. Irrigation method and status were determined using aerial image interpretation and land-cover classification methods. No information about crop type or other agricultural practices is included. The dataset incorporates information from available state and Federal mapping efforts and from analysis of aerial and satellite imagery.

\section{Description of Study Area}

For this study, the UCRB is defined as the contributing drainage basin of Hydrologic Unit Code (HUC) region 14 (fig. 1) as defined by the National Watershed Boundary Dataset (U.S. Department of Agriculture and others, 2013). The 10,100-mi ${ }^{2}$ Great Divide subbasin (HUC 14040200), northeast of the Continental Divide in Wyoming, is part of HUC 14 but is a closed basin and does not contribute runoff to the UCRB. The Great Divide subbasin has been excluded from the extent of the UCRB for this study. The study area has a contributing drainage area of about $109,500 \mathrm{mi}^{2}$.

The UCRB is bounded by the Wasatch Mountains in northern and central Utah to the west, the San Juan Mountains of Colorado and New Mexico to the southeast, the Wind River Range in west-central Wyoming to the north, and the Colorado Plateau to the south. Basin landscapes vary, ranging from high alpine to arid desert, and elevations range from 5,000 to over 14,000 ft for peaks along the Continental Divide. Annual precipitation ranges from about 40 in., mostly as snow, near the Continental Divide to less than 10 in. on the Colorado Plateau (PRISM Group, Oregon State University, 2007). Major river drainages in the UCRB include the Green, San Juan, and Colorado Rivers. Land cover in the basin is characterized by mixed desert scrub and rangeland, irrigated agriculture, and forested highlands. The largest urban area in the UCRB is Grand Junction, Colorado, with a population of approximately 58,500 (U.S. Census Bureau, 2010). Most of the water used in the UCRB is used for irrigated agriculture (Liebermann and others, 1989).

\section{Development of a Regionally Consistent Dataset of Agricultural Lands for the Upper Colorado River Basin}

For this study, agricultural lands are defined as lands used for the production of agricultural products grown for human and animal consumption or for growing ornamental or landscaping plants. These lands include pasture used for grazing livestock and lands used to produce agricultural products such as alfalfa, wheat, or other crops. Lawns, golf courses, recreational fields, and urban parks, where grass is irrigated solely for recreational use, were not included in the dataset.

Agricultural lands data in GIS format acquired from several sources (table 1) were gathered together and merged into a single GIS dataset. Ancillary data including satellite and aerial

Table 1. Sources of data used to develop the Upper Colorado River Basin dataset of agricultural lands.

[NA, not available]

\begin{tabular}{|c|c|c|c|c|}
\hline State & Source & Source & Date aquired & $\begin{array}{l}\text { Date(s) of } \\
\text { mapping }\end{array}$ \\
\hline Arizona & NA & NA & NA & NA \\
\hline Colorado & Colorado Decision Support Systems & http://cdss.state.co.us/GIS/Pages/DataByCategory.aspx & November 2011 & 2005 \\
\hline $\begin{array}{l}\text { New } \\
\text { Mexico }\end{array}$ & U.S. Bureau of Reclamation & David Eckhart, personal communication & October 2011 & 1998 \\
\hline $\begin{array}{l}\text { New } \\
\text { Mexico }\end{array}$ & New Mexico Interstate Stream Commission & Paul Harms, personal communication & April 2011 & 2009 \\
\hline Wyoming & Wyoming State Water Plan & http://waterplan.state.wy.us/plan/statewide/2007/gis/gis.html & November 2011 & 2007 \\
\hline
\end{tabular}


imagery were prepared and used to verify and classify the agricultural lands by irrigation method and irrigation status. Irrigation status was determined using an object-oriented classification scheme where a group of remote sensing images and ancillary data were input to an algorithm that partitions the images into segments with similar spectral and textural characteristics. Those segments were then grouped into three land-cover classes: irrigated lands, not irrigated lands, and water. The irrigated-lands class was used to identify polygons in the dataset that were likely irrigated during the study period.

\section{Preparation and Compilation of Source Data and Supporting Datasets}

Multiple data sources including agricultural-lands data in GIS format, aerial and satellite imagery, digital elevation data, percent tree canopy cover, and other base GIS data were compiled to develop the dataset of agricultural lands and to help classify the polygons by irrigation method and status. Data on agricultural lands were compiled from several sources and edited to match conditions on the ground during the study period. Aerial imagery was used to verify the extent and location of field boundaries as well as to provide clues to the type of irrigation system used to deliver water to the agricultural lands. Satellite data, tree canopy, and elevation data were used to help classify the irrigation status of the agricultural lands. Compilation of source data and satellite and aerial imagery is described in the following sections.

\section{Agricultural-Lands Data}

Datasets in vector GIS format for each state except Arizona were downloaded or acquired from the sources listed in table 1. In all cases, the data were composed of polygons representing field boundaries with accompanying tabular data used to add descriptive attributes to each polygon. Descriptive attributes included with each dataset varied by state but generally included the year the polygon was mapped, the irrigation status of the field, and, in some cases, the irrigation method. Completeness of the attributes varied. In the Colorado data, 11.5 percent of agricultural-land polygons in the study area were classified with irrigation method "unknown." All active fields in the data obtained from the New Mexico Interstate Stream Commission were classified with a valid irrigation method such as "sprinkler-" or "flood-irrigated." Inactive fields were classified as "fallow" in a crop-type attribute, and the attribute for irrigation method was empty. Data from the U.S. Bureau of Reclamation and data from Wyoming did not contain an attribute for irrigation method. Irrigation method was largely complete in the Utah data; dry or fallow fields were assigned a "null" or blank irrigation method in a manner similar to the New Mexico data. Source data were not available for the UCRB lands in Arizona. To develop data for Arizona, portions of the study area in the state were systematically reviewed in a GIS map against a background of aerial and satellite imagery. Visible disturbed areas that appeared to be used for agriculture were digitized into a new dataset.

The attribute table for each source agricultural-lands dataset was modified to fit a common structure. Source attributes, such as the irrigation method and status, the year the field was mapped, and the source of the data, were maintained in the modified attribute tables. New attributes for current irrigation status and method were included in the new table structure. The modified source datasets and the newly digitized Arizona data were merged into a single dataset and clipped to the extent of the study boundary. Some fields along the state boundaries overlapped where each state dataset included field boundaries that extended over the state line. These fields were split at a state boundary on the basis of the 2000 census tigerline cartographic boundary files (U.S. Census Bureau, 2000) and edge matched so that complete field boundaries were represented while maintaining the source of each portion of the field. The merged dataset was used as a base for irrigation method and status classification described below.

\section{Satellite Imagery}

Irrigation status can be determined from multispectral aerial or satellite images using well-established methods including image classification (Lo, 1986; Eckhart and others, 1990; Congalton and others, 1998; Ozdogan and Gutman, 2008) or simply on the basis of the evaluation of vegetation indices (Masoner and others, 2003) calculated from the reflectance recorded in multiple wavelength bands in a multispectral image such as collected by Landsat. Landsat is a group of Earth-observing satellites, the first of which was launched in 1972. Seven Landsat satellites have been successfully launched into orbit. Each of the satellites was equipped with one or more sensor instruments designed to collect imagery in several distinct spectral bands in the reflective visible and infrared and emitted thermal wavelengths (U.S. Geological Survey, 2012). Between 2003 and the launch of Landsat 8 in 2013, Landsat 5 was the only fully functional satellite remaining in orbit. Therefore, imagery acquired by the Thematic Mapper (TM) instrument aboard Landsat 5 was used for this study. The TM instrument collects information in six spectral bands with wavelengths ranging between the visible blue $(0.45 \mu \mathrm{m})$ and the short-wave infrared $(2.35 \mu \mathrm{m})$ and in a seventh band in the thermal infrared wavelengths between 10.4 and $12.5 \mu \mathrm{m}$. Continuous $180 \mathrm{~km}$-wide swaths of TM imagery are broken into overlapping "scenes" approximately $170 \mathrm{~km}$ in length. Each scene is imaged by the sensor every 16 days at $30-\mathrm{m}$ spatial resolution ( $120 \mathrm{~m}$ for the thermal channel) and covers approximately $31,110 \mathrm{~km}^{2}$. Landsat $5 \mathrm{TM}$ scene locations are identified using a World Reference System 2 (WRS2) path and row number. The UCRB is covered by paths 34 through 37 and rows 30 through 35 . Not all rows for each path are required to cover the study area (fig. 2).

Individual spectral bands or combinations of bands from a TM scene can be used to identify or characterize natural and anthropogenic features within the image. For example, 


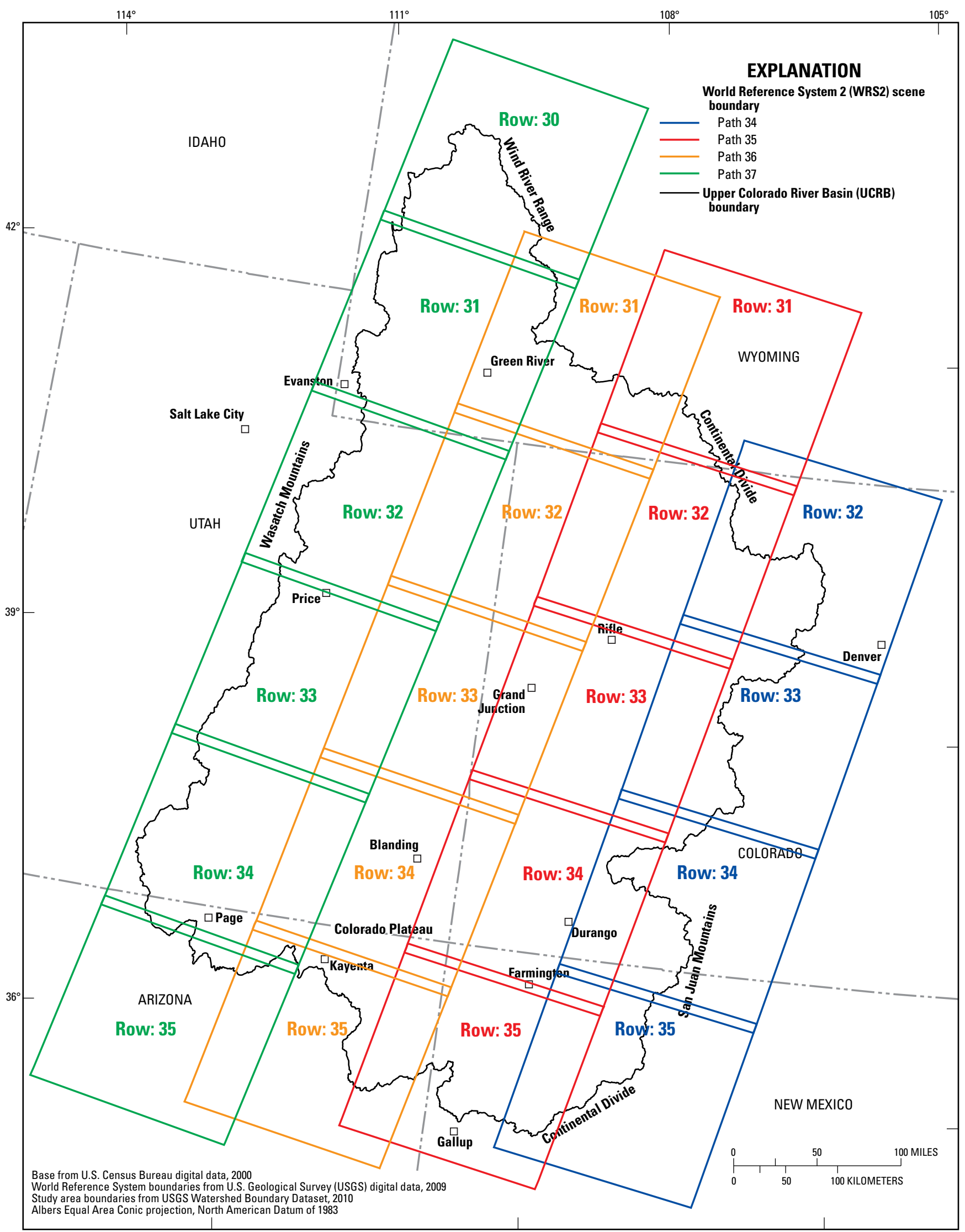

Figure 2. World Reference System 2 path and row scene boundaries covering the extent of the Upper Colorado River Basin study area. 
healthy vegetation absorbs light for use in photosynthesis in the red wavelengths collected in TM band $3(0.63-0.69 \mu \mathrm{m})$ and strongly reflects light in the near-infrared wavelengths collected in TM band $4(0.76-0.90 \mu \mathrm{m})$. Vegetation indices like the Normalized Difference Vegetation Index (NDVI) (Huete and others, 2002) use the contrast between these distinct absorption and reflectance features to help identify vegetated areas and to characterize the health and spatial extent of vegetation communities. Calculation of a vegetation index results in a unitless single-band image with valid values ranging between -1 and 1 . Vegetation index values in vegetated areas are generally greater than 0 and, in general, the healthier and denser the vegetation, the higher the vegetation index value.

Landsat scenes for the 2007-10 growing seasons were evaluated and selected from the image archive at the U.S. Geological Survey (USGS) Earth Resources Observation Systems (EROS) data center. The archive can be accessed from the USGS EarthExplorer interface (earthexplorer.usgs. gov). Multiple Landsat scenes across the growing season are required to capture phenological and harvest cycles in the agricultural lands under irrigation. Crops are planted and germinate at varying soil and atmospheric conditions, producing peak vigor at different times throughout a growing season. Some crops, like alfalfa, may be harvested multiple times throughout the season. Using multiple scenes to differentiate irrigated agricultural lands from native or non-irrigated agricultural lands increases the chance that a field will be captured at or near the peak of crop growth in at least one scene date. Scenes with less than 10 percent cloud cover captured by the TM sensor aboard Landsat 5 between June 1 and September 30 for each year were selected for each path and row shown on figure 2. September scenes were only selected when August scene availability was inadequate to represent the late growing season. The scene search was focused initially on the years 2009-10 to correspond with the National Agriculture Imagery Program (NAIP) acquisition dates identified early in the study. The 2011 NAIP imagery for New Mexico was substituted for the initial 2009 imagery after the Landsat scenes had been selected. Review of available scenes for 2009-10 revealed cloud-free or nearly cloud-free scenes for all months in the growing season were not available, resulting in gaps in the imagery collection. The search was extended backward to 2007 to allow for additional scenes to be included. If a cloud-free scene was available for 2009 or 2010, 2007 and 2008 scenes were not evaluated. Scenes from 2008 were given precedence over 2007 scenes. Selected scenes are listed in Appendix 1.

The Landsat TM images were calibrated to top of atmosphere (TOA) reflectance (Chander and others, 2009) to remove the effects of varying sun angles, Earth-to-sun distances, and TM sensor parameters. NDVI was calculated for each TOA image, and the resulting NDVI images were merged into a single NDVI image for each Landsat scene. The images were merged so the maximum NDVI value for all dates for a given scene was used in the final NDVI image. Selecting the maximum NDVI value removed low values resulting from plant phenology and harvest cycles. The maximum NDVI images were used as the basis for classification of irrigation status described below.

\section{Aerial Imagery}

NAIP imagery (U.S. Department of Agriculture, 2009) for the study area was acquired as image tiles clipped to the boundaries of USGS 1:24,000-scale quarter-quadrangle boundaries. NAIP images are collected on a state-by-state basis. Imagery for Arizona was produced in 2010. Colorado, Utah, and Wyoming data were produced in 2009. The New Mexico data initially selected for use in this study were collected in 2009, but 2011 data were released during the course of the study and were used in place of the 2009 data. The $1-\mathrm{m}$ spatial resolution NAIP imagery was delivered as uncompressed 3-band (red, green, and blue) images. The NAIP imagery was the basis of the aerial image interpretation used to determine irrigation method and also was used as an ancillary data layer for the classification of irrigation status.

\section{Classification of Irrigation Method and Editing for Spatial Accuracy}

The study area was subset into 24 polygon "tiles" on the basis of modified WRS2 scene boundaries. The WRS2 boundaries were modified by removing overlapping areas between scenes and removing excess area from the polygons at the boundary of the study area to reduce the tile size. Large polygons in the center of the study area were divided to create east and west halves to further reduce tile size. The tiles were numbered on the basis of their source WRS2 path and row. For example, WRS2 path 35 row 34 became tile p35r34. WRS2 path 36 row 33 was divided into tiles p36r33E (east) and p36r33W (west) (fig. 3A).

The merged dataset of agricultural lands was clipped to the boundary of the WRS2 tiles creating 24 sub-datasets that were assessed individually for irrigation method. Topology was created for each sub-dataset, and overlapping polygons were evaluated and edited where necessary. After the topology was cleaned, data within each WRS2 tile were evaluated systematically in a GIS map using a "review grid" overlain on the tile (fig. 3). The review grid was composed of rectangular polygon cells each covering approximately $24 \mathrm{mi}^{2}$. Polygons of agricultural lands within each review grid cell were assessed for spatial accuracy and irrigation method; polygons were marked "reviewed" once the examination was finished. Ancillary datasets in the map during review included the 1-m color NAIP imagery, the maximum NDVI value, and the High Resolution National Hydrography Dataset (NHD). The NHD is a comprehensive set of digital spatial data that represents the surface water of the United States using common features such as lakes, ponds, streams, rivers, canals, streamgages, and dams (Simley and Carswell, 2009). The NHD was symbolized in the map to highlight the mapped location of irrigation canals. 

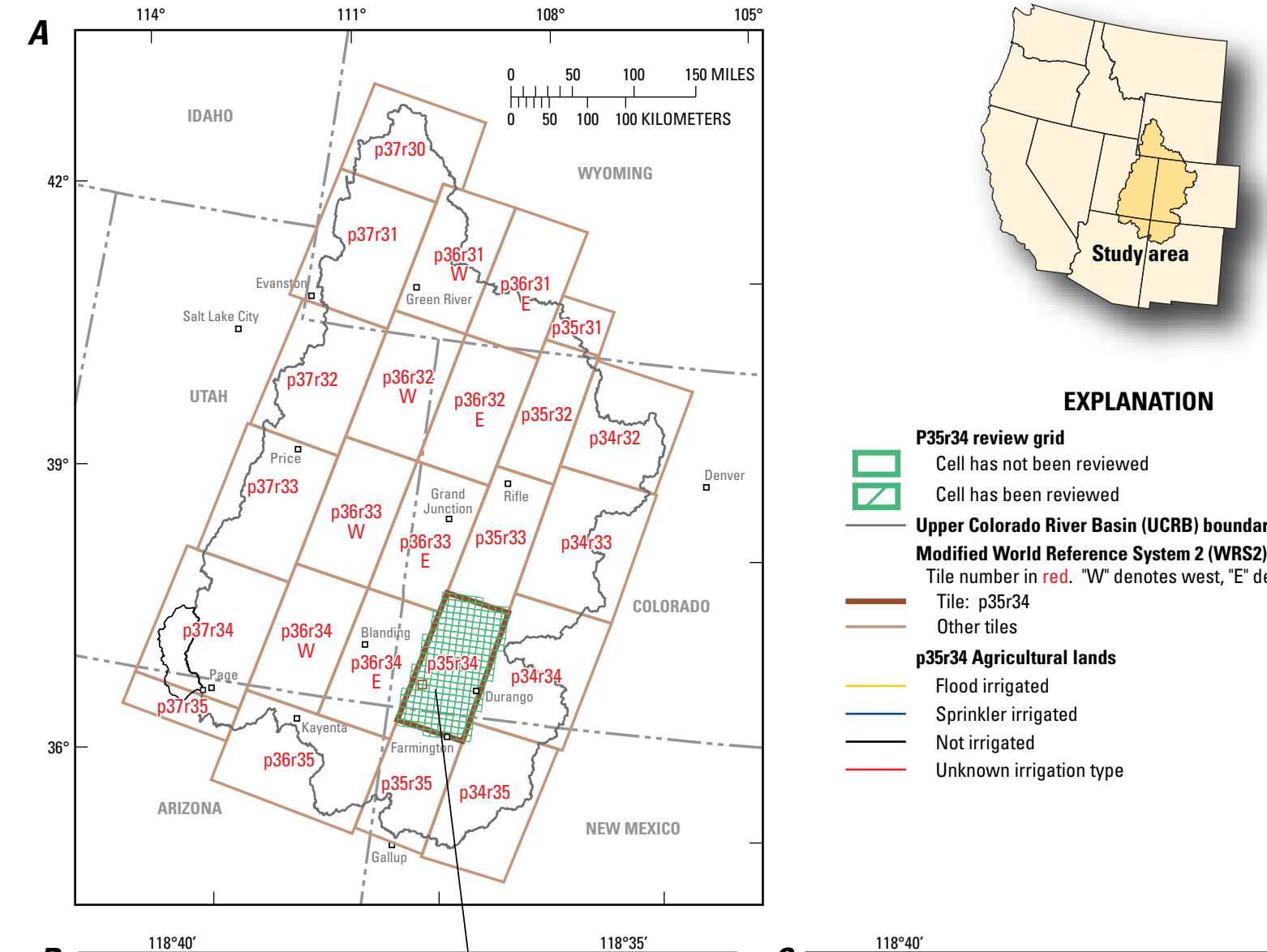

\section{EXPLANATION}

\section{P35r34 review grid}

Cell has not been reviewed

Cell has been reviewed

Upper Colorado River Basin (UCRB) boundary

Modified World Reference System 2 (WRS2) tiles and number Tile number in red. "W" denotes west, "E" denotes east

Tile: p35r34 Other tiles

p35r34 Agricultural lands

Flood irrigated

Sprinkler irrigated

Not irrigated

Unknown irrigation type

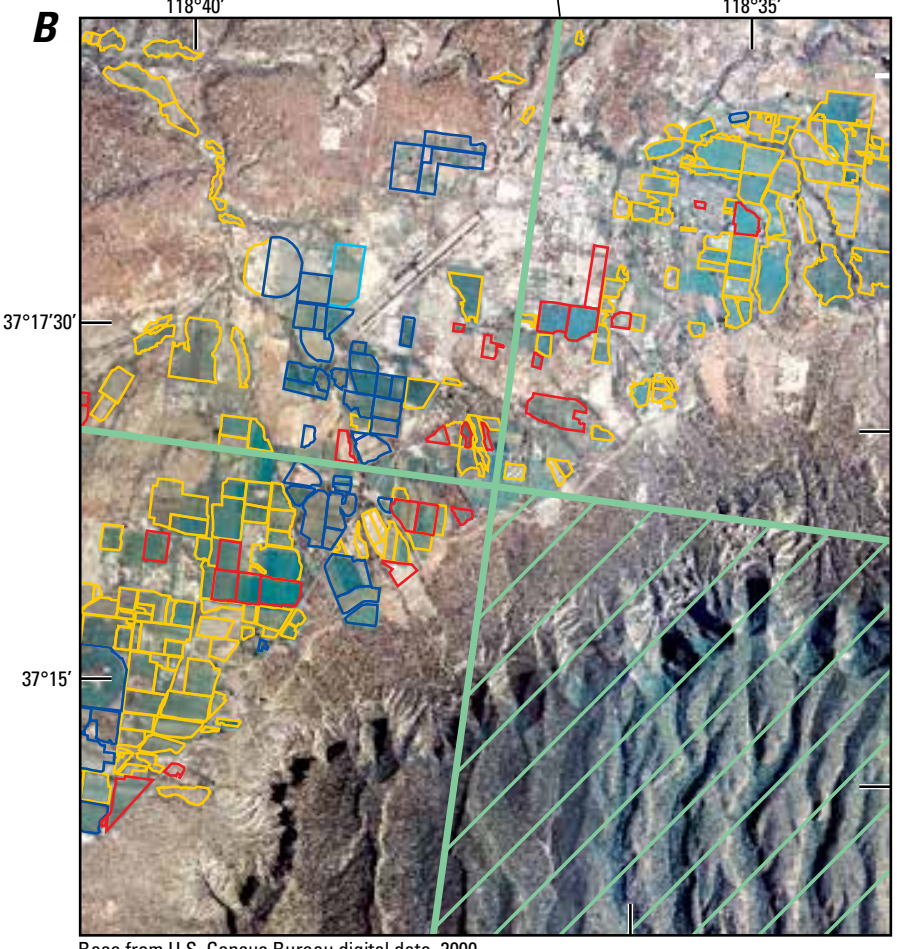

Study area boundary from U.S. Geological Survey (USGS) Watershed Boundary Dataset, 2010 World Reference System tile boundaries modified from USGS digital data, 2009 Albers Equal Area Conic projection, North American Datum of 1983

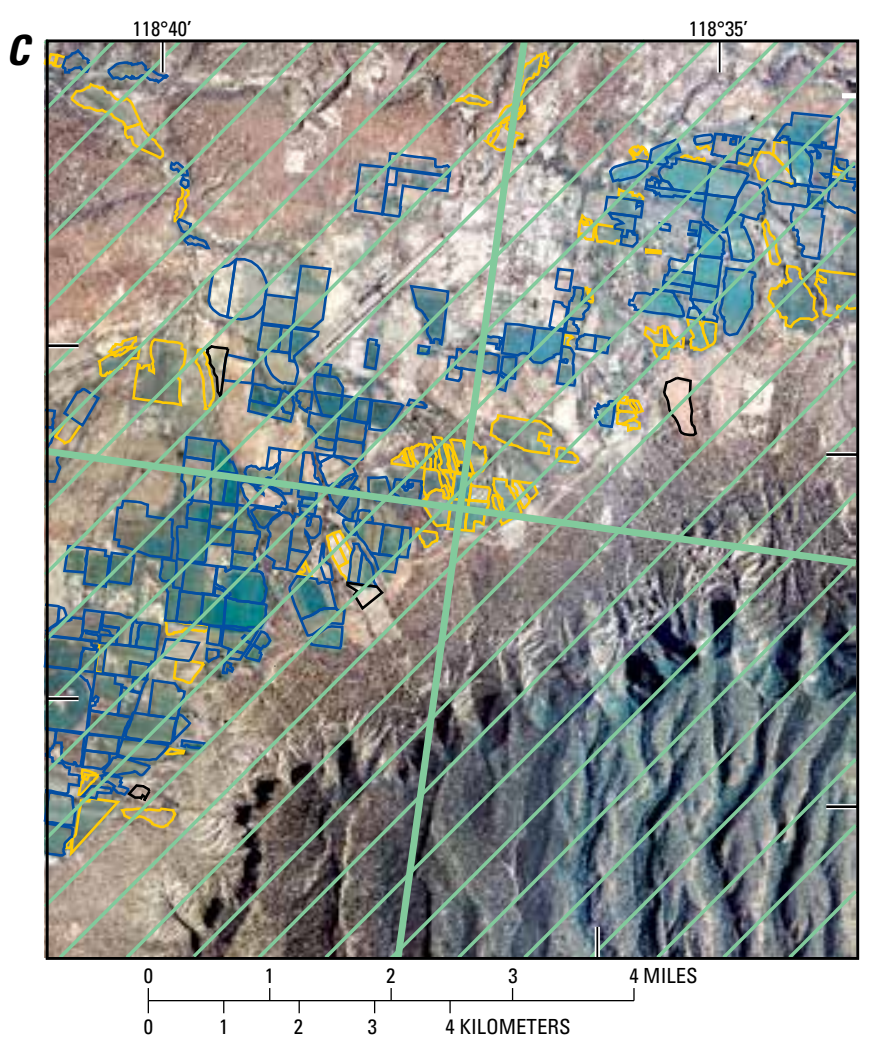

Figure 3. A, Modified World Reference System 2 scene boundaries and polygon cells used to manage dataset review; and $B$, agricultural field polygons before editing; and $C$, after editing in part of the Upper Colorado River Basin study area. 
The agricultural lands within each review grid cell were evaluated against the NAIP imagery for spatial accuracy and irrigation method. Spatial accuracy was assessed by evaluating the existing field boundary against the NAIP imagery and revising or removing the boundary where necessary. Boundaries that were within the expected error of approximately $14 \mathrm{~m}$ for digital 1:24,000-scale mapping (Federal Geographic Data Committee, 1998) were not edited. Field polygons were deleted if the field no longer appeared to be an active agricultural field because of a land-use change such as urbanization. Fields also were deleted from the dataset if they did not appear to be irrigated agricultural lands used for crop production or livestock grazing. Golf courses and other sports complexes such as baseball diamonds were removed from the dataset because they did not fit the definition of agricultural lands used for this study. Fields larger than 5 acres that were omitted from the source data were added to the dataset. Fields smaller than 5 acres may exist in the final dataset if they were present in the source data.

Irrigation methods used for this study were flood, sprinkler, other, and unknown-not irrigated. For this study, flood irrigation encompasses any irrigation method that releases water over the land surface and floods the entire field or fills furrows in the field with water. Sprinkler methods use pipes and sprinkler heads to deliver water to the plants. The classification "other" encompasses irrigation methods that cannot be classified as either sprinkler or flood irrigated. Fields that did not appear to be irrigated during the study period but that appeared to be agricultural lands were classified "unknownnot irrigated." For example, large areas in Utah classified as "dry agriculture" in the source data are classified "unknownnot irrigated" in the final dataset. Fields that appeared to be fallow with no visual evidence of irrigation method were also classified "unknown-not irrigated." All field polygons in the final dataset are classified with some method.

Irrigation method was assigned to field polygons on the basis of information gathered from the NAIP imagery, the source polygons, and from other ancillary datasets. Where possible, irrigation method was determined using interpretation of the NAIP imagery. Information from the source data and from ancillary datasets like the NHD was used to improve or support the classification. Examination of agricultural areas in the NAIP reveals physical features that can help identify the type of irrigation used on a field (fig. $4 A-C$ ). Center pivot sprinkler-irrigated lands are most easily identified by their circular or semi-circular forms in the imagery (fig. $4 A$ ). Active or recently active lateral or wheel line sprinklers leave a distinct linear wetting front visible in the imagery (fig. $4 B$ ). In the absence of a wetting pattern, the sprinkler mechanism is often clearly visible as a linear feature in the imagery (fig. $4 C$ ). Indications that a field is irrigated by flood methods include uneven wetting or overland flow patterns, pipes used to deliver water visible in the field, and visible furrows or canals in the field. Some of these features are visible in figure $4 D$. If the field was classified for type in the source dataset, the classification was left intact unless image interpretation and information from ancillary datasets indicated the field was misclassified in the source dataset or the irrigation method had changed since being mapped by the source. If the source data included an irrigation method that did not fit into the broad categories used by this study, such as drip irrigation, the field was classified "other." The source data in a small area of fields in WRS2 tile p35r34 is shown in figure $3 B$. The result of spatial-data editing and irrigation-method reclassification of those fields is shown in figure $3 C$. Once review and digitizing were complete, the datasets were combined and edgematched by merging the 24 sub-datasets into a single dataset and merging and matching field boundaries along the seams of the WRS2 tile boundaries.

The final UCRB dataset of agricultural lands contains polygons representing approximately 1,759,900 acres of agricultural land. The data are comprised of 59.5 percent flood-irrigated lands, 23 percent sprinkler-irrigated lands, and 17.5 percent classified unknown-not irrigated. Other irrigation methods such as drip irrigation account for less than 0.03 percent of the total lands in the final dataset. Classification of irrigation method does not mean the field was irrigated during the study period. Fields that were not irrigated during the study period may have an irrigation method assigned to them if the field was irrigated at some time and the irrigation method was apparent from the image analysis or the source dataset. Classification of irrigation status is discussed in the following section.

\section{Classification of Irrigation Status}

Irrigation status was assessed for the June through September growing seasons from 2007 through 2010 using objectoriented image segmentation and classification. The overall objective of image classification procedures is to automatically categorize all pixels in an image into land-cover classes or themes (Lillesand and others, 2008). Classification algorithms fall into two broad categories: supervised and unsupervised. Supervised classification algorithms use training information supplied by the user to organize the scene into landcover classes. Training is a process by which selected image elements are placed into land-cover classes. Information extracted from the training dataset is used to place the remaining image pixels into those land-cover classes. Unsupervised algorithms group similar pixels or objects solely on the basis of information taken from the image. The user then groups the results into land-cover classes. Supervised and unsupervised classification can employ spectral or object-oriented methods to detect similar elements in the image. Spectral classification techniques use only spectral characteristics to classify an image on a pixel-by-pixel basis. The basis of object-oriented classification or "feature extraction" is the partitioning of an image into segments that are composed of groups of image pixels with similar spectral and textural characteristics. Segments are clusters of adjacent pixels that represent a meaningful object on the terrain from the user point of view (Geneletti 

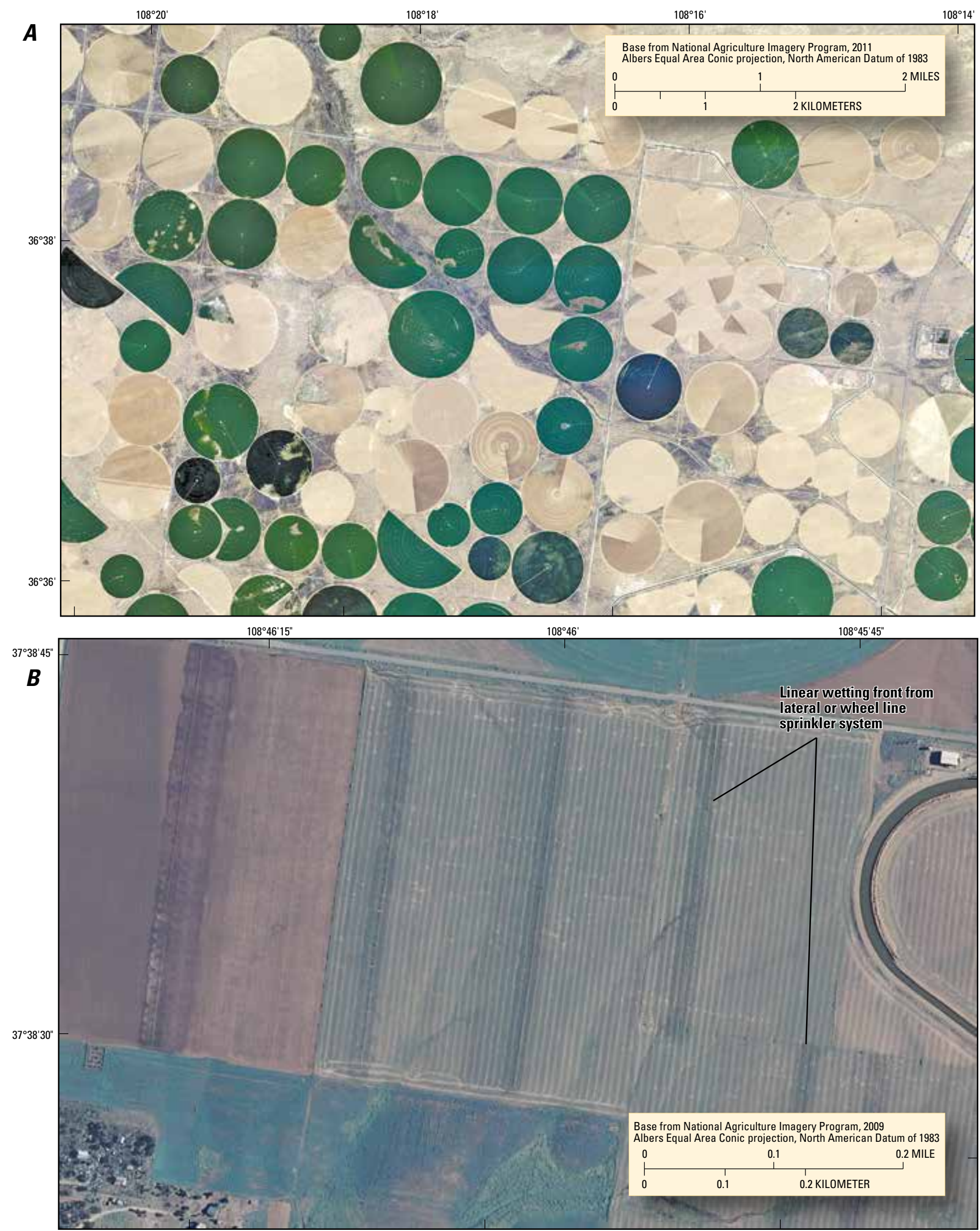

Figure 4. National Agricultural Imagery Program images showing examples of image interpretation techniques used to determine irrigation method used for $A$, center pivot irrigation; $B$, lateral or wheel line irrigation; $C$, center pivot and wheel line irrigation; and $D$, flood irrigation. 


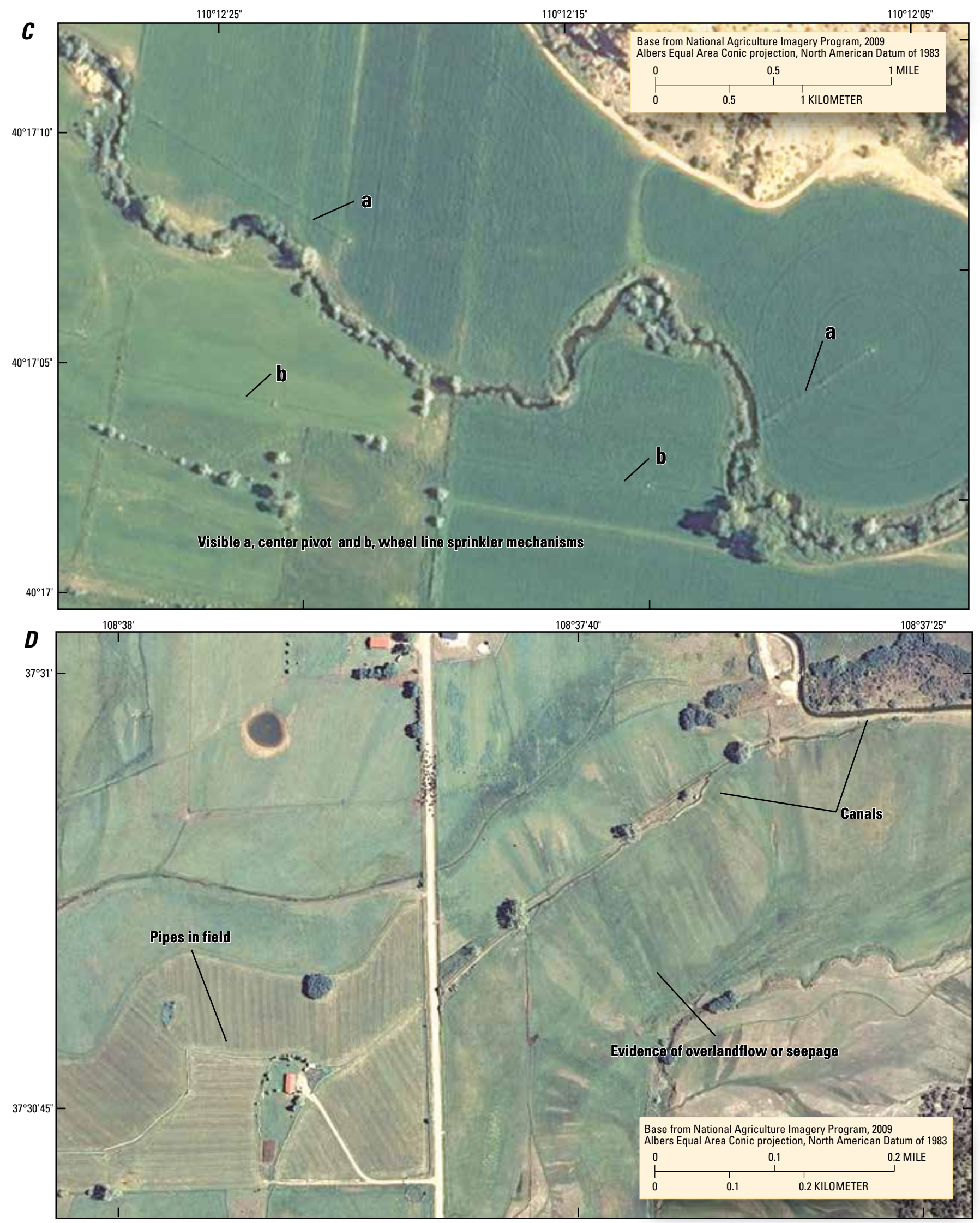

Figure 4. National Agricultural Imagery Program images showing examples of image interpretation techniques used to determine irrigation method used for $A$, center pivot irrigation; $B$, lateral or wheel line irrigation; $C$, center pivot and wheel line irrigation; and $D$, flood irrigation.-Continued 
and Gorte, 2003). With spectrally homogeneous segments of images, spectral values and spatial properties, such as size and shape, can be explicitly utilized as features for further classification (Yu and others, 2006). Segments are treated as objects or features and are further classified into similar land-cover classes using a classification algorithm.

The classification scheme used for this study consisted of three land-cover classes: irrigated agricultural land, other land, and water. Healthy native vegetation such as forest and native meadow can be misclassified as irrigated land when using simple spectral classification techniques unless distinct spectral properties can be discerned from the wavelengths available to the classifier. Object-oriented classification allows input from ancillary datasets such as elevation, slope, or aspect derived from a digital elevation model (DEM). Ancillary datasets input to the classification can support a conceptual model of the land-cover classes to be identified and improve the accuracy of the classification. For this study, it was assumed that irrigated agriculture should have high NDVI values compared to native shrub lands, be located on relatively level land, and have low percent tree canopy cover with the exception of orchards and tree farms.

Four datasets supporting the conceptual model of agricultural lands were input to the image segmentation and classification process used for this study. All images were clipped to the boundary of the 24 WRS2 tiles (fig. $3 A$ ), and processing was completed on each tile. The first input dataset was the maximum NDVI image described earlier. A second input image was developed by merging a derivative of the 1-m NAIP data and a mid-summer Landsat scene for each WRS2 tile. This image was produced by first resampling NAIP compressed county mosaic data (U.S. Department of Agriculture, 2009) to 10-m spatial resolution. The resampled NAIP county mosaic data were merged to create an image with a spatial extent that overlapped each of the WRS2 tiles. Finally, the three NAIP bands were merged to create a single-band high-resolution image. Each single-band image was merged with a mid-summer Landsat scene from the same WRS2 tile. The merge was done using a high-pass filter (HPF) resolution merge algorithm. This process merges the spatial information of the higher spatial resolution dataset with the spectral information of the higher spectral resolution dataset (Chavez and others, 1991). In this case, the result was a 10-m resolution image with the spectral characteristics of the Landsat image and the textural or spatial characteristics of the NAIP imagery. Percent tree canopy density from the 2001 National Land Cover Dataset (NLCD) (Homer and others, 2007) was input to help reduce misclassifications resulting from elevated NDVI values in areas of moderate to high canopy cover where little to no irrigated agriculture is assumed to occur. Finally, slope calculated from the 1/3 arc-second (10-m) National Elevation Dataset (NED) (U.S. Geological Survey, 2002) was included in the data stack input for segmentation.

Each set of data layers for each WRS2 tile was processed using the feature extraction module in the ENVI software environment (EXELIS Visual Information Systems, 2014).
The software merges the input layers and partitions the merged layers into spectrally and texturally similar segments. Those segments were passed through a supervised classification process where segments were interactively selected to train the classifier. In the absence of training data collected from field visits, irrigated lands were selected by assuming a base NDVI threshold from the maximum NDVI image within the polygons of agricultural lands. Image segments falling within an agricultural-land polygon and above the threshold were assigned to the "irrigated" lands class. Training data were also selected and assigned to the "not irrigated" and "water" classes. The image segments and training data were then passed through a support vector machine (SVM) classification method. SVMs are a group of machine-learning algorithms that employ optimization algorithms to locate the optimal boundaries between classes (Huang and others, 2002). After classification was complete, the irrigated-lands class from each WRS2 tile was combined with the agricultural-lands polygons by intersecting the two datasets in a GIS. The resulting data were assessed and agricultural-lands polygons that had 50 percent or more of their area classified as irrigated were assumed to have been irrigated during the study period. All other agricultural-lands polygons were classified "not irrigated." The results were evaluated for logical consistency so that no agricultural-lands polygons were classified "irrigated" in the irrigation status attribute and classified as "unknownnot irrigated" in the irrigation method attribute. Field polygons also were checked to verify that all attributes were complete and no other logical errors existed.

The final irrigation status resulted in approximately $1,159,900$ acres classified as irrigated and 600,000 acres classified as not irrigated (fig. 5). Irrigated acreage represents 65.9 percent of the total acres of agricultural lands in the dataset. Note, fields not irrigated during the study period may have an irrigation method assigned to them if the field was irrigated at some time and the irrigation method was apparent from the image analysis or the source dataset. Total irrigated and non-irrigated acreage and irrigation method for each state are tabulated in table 2. Colorado and Utah contain the most agricultural lands with 51.8 and 25.4 percent of the total agricultural area in the UCRB, respectively. Wyoming and Colorado agricultural lands in the UCRB are most commonly irrigated using flood methods with 78.2 and 51.6 percent of the total agricultural lands irrigated during the study period, respectively. Sprinkler methods are more common in New Mexico and Utah with 65.4 and 35.2 percent of the total agricultural lands irrigated during the study period within the UCRB, respectively.

The data on irrigated lands are available in GIS format from the USGS from http://water.usgs.gov/lookup/ getspatial?sir2014_5039_UCRBAgriculture. 


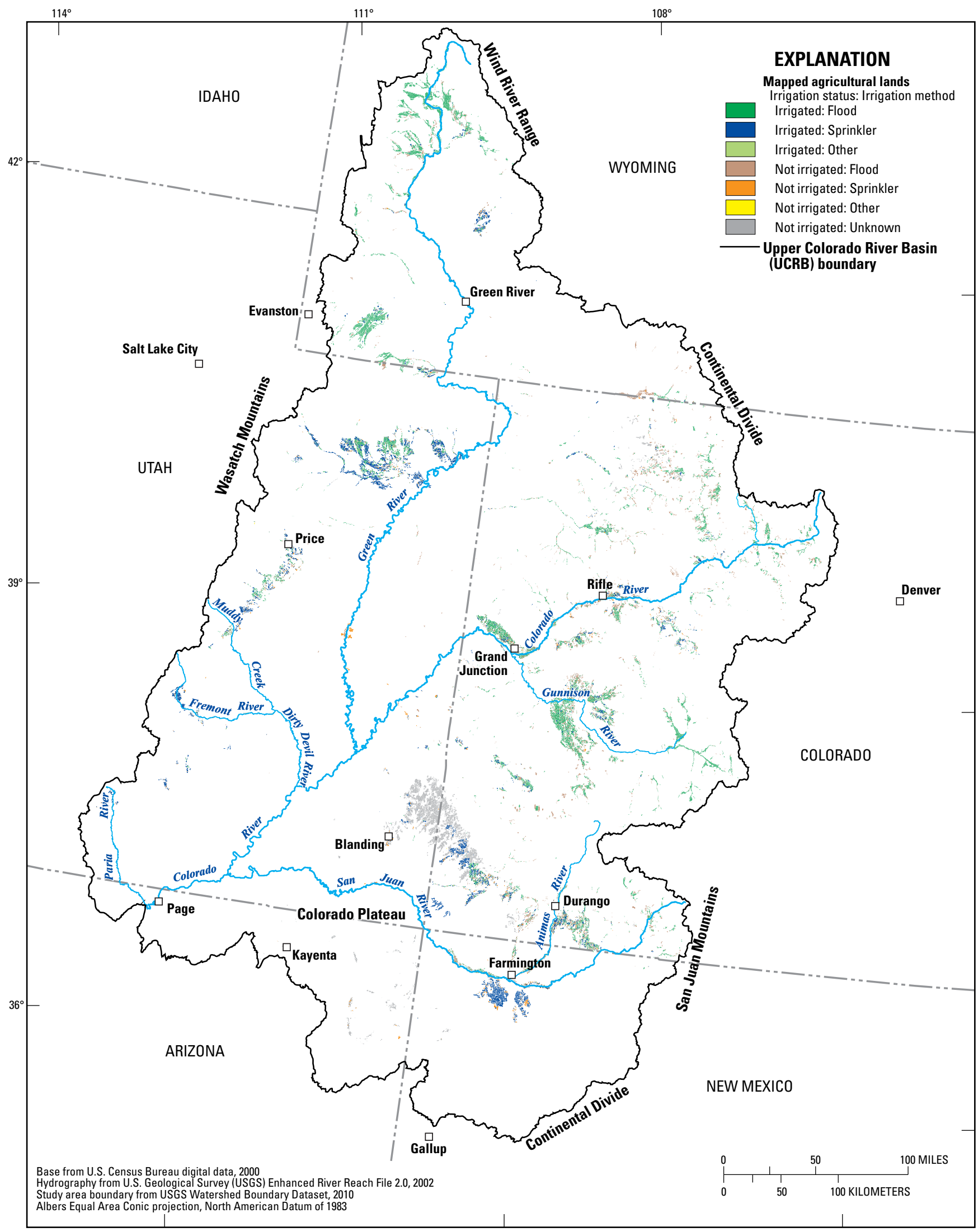

Figure 5. Agricultural lands in the Upper Colorado River Basin 2007-10 showing fields classified as irrigated and not irrigated and the method used to irrigate the field. 
Table 2. Summary of irrigation status and method by state for the Upper Colorado River Basin, 2007-10.

[UCRB, Upper Colorado River Basin]

\begin{tabular}{|c|c|c|c|c|c|}
\hline State & Irrigation status & Irrigation method & Area (acres) & $\begin{array}{l}\text { Percent of } \\
\text { total area in } \\
\text { UCRB }\end{array}$ & $\begin{array}{l}\text { Percent for } \\
\text { state }\end{array}$ \\
\hline \multirow[t]{6}{*}{ Arizona } & Irrigated & Sprinkler & 3 & 0 & 0 \\
\hline & Not irrigated & Sprinkler & 918 & 0.1 & 7.1 \\
\hline & \multirow[t]{4}{*}{ Not irrigated } & Unknown, not irrigated & 12,012 & 0.7 & \multirow[t]{4}{*}{92.9} \\
\hline & & Total irrigated & 3 & 0 & \\
\hline & & Total not irrigated & 12,930 & 0.7 & \\
\hline & & State total & 12,933 & 0.7 & \\
\hline \multirow[t]{10}{*}{ Colorado } & Irrigated & Flood & 470,268 & 26.7 & 51.6 \\
\hline & Irrigated & Sprinkler & 115,076 & 6.5 & 12.6 \\
\hline & Irrigated & Other & 54 & 0 & 0 \\
\hline & Not irrigated & Flood & 182,029 & 10.3 & 20 \\
\hline & Not irrigated & Sprinkler & 14,169 & 0.8 & 1.6 \\
\hline & Not irrigated & Other & 121 & 0 & 0 \\
\hline & \multirow[t]{4}{*}{ Not irrigated } & Unknown, not irrigated & 130,078 & 7.4 & \multirow[t]{4}{*}{14.3} \\
\hline & & Total irrigated & 585,398 & 33.3 & \\
\hline & & Total not irrigated & 326,397 & 18.5 & \\
\hline & & State total & 911,795 & 51.8 & \\
\hline \multirow[t]{9}{*}{ New Mexico } & Irrigated & Flood & 10,993 & 0.6 & 11.2 \\
\hline & Irrigated & Sprinkler & 63,982 & 3.6 & 65.4 \\
\hline & Not irrigated & Flood & 6,792 & 0.4 & 6.9 \\
\hline & Not irrigated & Sprinkler & 9,101 & 0.5 & 9.3 \\
\hline & Not irrigated & Other & 4 & 0 & 0 \\
\hline & \multirow[t]{4}{*}{ Not irrigated } & Unknown, not irrigated & 6,950 & 0.4 & \multirow[t]{4}{*}{7.1} \\
\hline & & Total irrigated & 74,975 & 4.3 & \\
\hline & & Total not irrigated & 22,847 & 1.3 & \\
\hline & & State total & 97,822 & 5.6 & \\
\hline \multirow[t]{10}{*}{ Utah } & Irrigated & Flood & 91,306 & 5.2 & 20.5 \\
\hline & Irrigated & Sprinkler & 157,173 & 8.9 & 35.2 \\
\hline & Irrigated & Other & 215 & 0 & 0 \\
\hline & Not irrigated & Flood & 23,021 & 1.3 & 5.2 \\
\hline & Not irrigated & Sprinkler & 19,300 & 1.1 & 4.3 \\
\hline & Not irrigated & Other & 93 & 0 & 0 \\
\hline & \multirow[t]{4}{*}{ Not irrigated } & Unknown, not irrigated & 155,355 & 8.8 & \multirow[t]{4}{*}{34.8} \\
\hline & & Total irrigated & 248,694 & 14.1 & \\
\hline & & Total not irrigated & 197,769 & 11.2 & \\
\hline & & State total & 446,463 & 25.4 & \\
\hline \multirow[t]{11}{*}{ Wyoming } & Irrigated & Flood & 227,543 & 12.9 & 78.2 \\
\hline & Irrigated & Sprinkler & 23,279 & 1.3 & 8 \\
\hline & Not irrigated & Flood & 34,762 & 2 & 12 \\
\hline & Not irrigated & Sprinkler & 2,010 & 0.1 & 0.7 \\
\hline & Not irrigated & Unknown, not irrigated & 3,237 & 0.2 & 1.1 \\
\hline & & Total irrigated & 250,822 & 14.3 & \\
\hline & & Total not irrigated & 40,009 & 2.3 & \\
\hline & & State total & 290,831 & 16.5 & \\
\hline & & UCRB total irrigated & $1,159,892$ & 65.9 & \\
\hline & & UCRB total not irrigated & 599,952 & 34.1 & \\
\hline & & UCRB total & $1,759,844$ & & \\
\hline
\end{tabular}

\section{Limitations and Considerations of Methodology}

Classification of irrigation method was based solely on image interpretation with no field verification. Errors are likely because of misinterpretation of the imagery and lack of sufficient information to make an informed decision. Some sprinkler irrigation may be missed if the work is performed with small sprinklers or if the wheel line mechanism has been moved from the field or is placed along a fence line during the time the imagery was acquired. Irrigation method from the source datasets was retained in instances where the NAIP imagery did not offer conclusive evidence. The source information may be out-of-date because irrigation systems change over time in the study area.

Classification errors are expected in any land-cover classification, and misclassification of irrigation status in some areas is likely. Fields that were unevenly wetted or watered infrequently may be classified as not irrigated. Feature extraction was used to assess the feasibility of extracting precisely delineated field boundaries using the classification algorithm. Fields that were evenly wetted and of uniform shape resulted in reasonable estimations of the field boundary, but unevenly watered and irregular fields did not result in clean feature extraction. Using an automated classification method allows the algorithm to make the classification decision and is a repeatable result. The classification results still contain misclassified segments where riparian or other healthy vegetation exists.

The time period for the study did not allow for field verification of irrigation status because the classification work was completed several years after image acquisition. The timing was limited to the years of NAIP acquisition so that field boundaries could be more accurately delineated. Field boundaries may have changed since the last NAIP acquisition.

\section{Accuracy Assessment}

Assessment of map accuracy falls into two broad categories-positional and thematic. Positional accuracy was not formally assessed for this study. Systematic 
review of field boundaries against the NAIP imagery was done with the intent to maintain positional accuracy of the data at approximately 1:24,000 scale.

Any thematic map classification will contain error that may result from inaccuracy in any of several potential areas including radiometric correction procedures, inherent variability in the surface being measured, scaling errors, uncertainty in training pixels, and failures in the classification algorithm (Jones and Vaughan, 2010). Irrigation method and status were evaluated to estimate the overall accuracy of the final data product.

Irrigation method may be misclassified because of human error, misinterpretation of the imagery, or lack of clear evidence in the imagery to determine irrigation method. The accuracy of the irrigation method was assessed by selecting a stratified random sample of 150 fields for the flood- and sprinkler-irrigated classes. The number of fields was selected on the basis of an empirically derived rule presented in Congalton and Green (2009) that suggests maps larger than 1 million acres in size should receive a minimum of 75 to 100 accuracy assessment sites per class. The selected fields were stripped of all identifying attributes and split into two groups that were classified for irrigation method by separate users. The users were allowed to classify fields "sprinkler," "flood," or "unknown-can't determine." The results were combined and compared with the final UCRB agriculture dataset. The overall map accuracy for sprinkler- and flood-irrigated fields is 78.7 percent (table 3). The "producer's accuracy" is estimated to be 80.4 percent for flood-irrigated fields and 88 percent for sprinkler-irrigated fields. The producer's accuracy is a measure of the probability that a sample field is correctly classified (Story and Congalton, 1986). The "user's accuracy," or probability that a sample from the map actually represents that map category on the ground for flood-irrigated fields is 79.3 percent and 78 percent for sprinkler-irrigated fields. Irrigation method was unclear and not determined in 19 of the samples.

The accuracy of irrigation status was not directly assessed because of the time difference between the classification of irrigation status and the implementation of this study. The automated classification technique was compared against visual human interpretation of irrigation status to evaluate the effectiveness of each technique by comparing 150 randomly selected fields. The fields were classified for irrigation status using the maximum NDVI images for each Landsat scene tile described earlier. Each field was assessed against the NDVI and manually classified as irrigated or not irrigated. This classification was compared with the automated classification. The manual method and automated method agreed for 83.3 percent of the fields (table 4). In the absence of reference samples collected from field reconnaissance of the area, this evaluation is assumed to be representative of the overall accuracy of the irrigation status classification in the study area.

The 2007 Census of Agriculture (U.S. Department of Agriculture, 2007) tabulated 1,357,400 acres of land in irrigation and 1,958,400 acres of total cropland in the UCRB excluding the Great Divide subbasin. Total cropland differs between the UCRB dataset of agricultural lands and the 2007 Census of Agriculture by about 10 percent; the total area of irrigated lands differs by 14.5 percent. These values are within the errors outlined in the accuracy assessment. Discrepancies between the total area reported by the census and the UCRB agricultural-lands dataset may be because of misclassifications of irrigation status in existing fields, omission of field boundaries from the agricultural-lands dataset, and errors and omissions in reporting or compilation of the census of agriculture data.

Table 3. Assessment of the accuracy of irrigation method classification.

\begin{tabular}{|c|c|c|c|c|c|c|}
\hline & \multirow{5}{*}{$\begin{array}{l}\text { Map } \\
\text { irrigation } \\
\text { status }\end{array}$} & \multicolumn{5}{|c|}{ Reference irrigation method } \\
\hline & & \multirow{4}{*}{$\begin{array}{r}\text { Flood } \\
\text { Sprinkler } \\
\text { Column total }\end{array}$} & Flood & Sprinkler & $\begin{array}{l}\text { Unknown, } \\
\text { can't } \\
\text { determine }\end{array}$ & Row total \\
\hline & & & & 16 & 15 & 150 \\
\hline & & & 29 & 117 & 4 & 150 \\
\hline & & & 148 & 133 & 19 & \\
\hline Sum of the major diagonal ${ }^{1}$ & 236 & & & & & \\
\hline Total number of samples & 300 & & & & & \\
\hline Overall accuracy $(236 / 300)$ & 78.7 & & & & & \\
\hline \multicolumn{7}{|l|}{ Producer's accuracy } \\
\hline Flood irrigated (119/148) & 80.4 & & & & & \\
\hline Sprinkler irrigated (117/133) & 88.0 & & & & & \\
\hline \multicolumn{7}{|l|}{ User's accuracy } \\
\hline Flood irrigated (119/150) & 79.3 & & & & & \\
\hline Sprinkler irrigated $(117 / 150)$ & 78.0 & & & & & \\
\hline
\end{tabular}

${ }^{1}$ The sum of the major diagonal is the sum of samples correctly classified in the mapped data. 
Table 4. Assessment of automated and manual irrigation status classifications.

\begin{tabular}{|c|c|c|c|c|c|}
\hline & \multirow{5}{*}{$\begin{array}{c}\text { Map } \\
\text { irrigation } \\
\text { status }\end{array}$} & & \multicolumn{2}{|c|}{ Reference irrigation status } & \multirow[b]{2}{*}{ Row total } \\
\hline & & \multirow{4}{*}{$\begin{array}{l}\text { Irrigated } \\
\text { Not irrigated } \\
\text { Column total }\end{array}$} & Irrigated & Not irrigated & \\
\hline & & & 92 & 18 & \multirow{3}{*}{$\begin{array}{r}110 \\
40\end{array}$} \\
\hline & & & 7 & 33 & \\
\hline & & & 99 & 51 & \\
\hline Sum of the major diagonal ${ }^{1}$ & 125 & & & & \\
\hline Total number of samples & 150 & & & & \\
\hline Overall accuracy $(125 / 150)$ & 83.3 & & & & \\
\hline \multicolumn{2}{|l|}{ Producer's accuracy } & & & & \\
\hline Irrigated (92/99) & 92.9 & & & & \\
\hline Not irrigated (33/51) & 64.7 & & & & \\
\hline \multicolumn{2}{|l|}{ User's accuracy } & & & & \\
\hline Irrigated $(92 / 110)$ & 83.6 & & & & \\
\hline Not irrigated (33/40) & 82.5 & & & & \\
\hline
\end{tabular}

${ }^{1}$ The sum of the major diagonal is the sum of samples correctly classified in the mapped data.

\section{Summary}

In arid regions of the world, natural rainfall is not sufficient to meet the water requirements for growing crops. In these regions, crops are irrigated by the application of water through a delivery system such as sprinklers, furrows, or pipes to make up the difference between available rainfall and the water requirement of the crop. Delineating accurate boundaries for agricultural lands, determining irrigation status of those lands, and further differentiating between land irrigated by flood and sprinkler methods is important to help understand dissolved-solids loading and transport in the Upper Colorado River Basin (UCRB) and to help focus and prioritize salinity control efforts in the basin. In addition, consumptive water-use estimates in the basin rely on accurate maps of the location and extent of irrigated agriculture.

Agricultural lands in the UCRB have been mapped in GIS format by various entities using different methods and for different time periods. Existing datasets were used to develop a temporally and spatially consistent regional dataset for the UCRB to acquire a regional view of agriculture and irrigation in the basin. Existing data were modified to fit a single format and merged together. The merged dataset was then evaluated and field boundaries edited, removed, or added as necessary to match conditions visible in 2009-11 NAIP imagery. Landsat imagery was used in conjunction with ancillary datasets to perform a classification to determine the location of agricultural fields that were likely irrigated during the June through September growing seasons between 2007 and 2010. The final dataset contains polygons representing approximately 1,759,900 acres of agricultural land. The data are comprised of 59.5 percent flood-irrigated lands,
23 percent sprinkler-irrigated lands, and 17.5 percent classified as unknown-not irrigated. Other irrigation methods account for less than 0.03 percent of the total lands in the final dataset. Irrigated acreage represents 65.9 percent of the agricultural lands in the dataset during the study period. Accuracy of the classification of irrigation status was assessed by comparing the classified dataset against a manual assessment of irrigation status. The two methods agreed in 83.3 percent of the evaluated samples. Accuracy of irrigation-method classification was compared against an independent assessment of irrigation method. The two methods agreed in 78.7 percent of the sample fields. The irrigated-lands data are available in GIS format from the USGS at http://water.usgs.gov/lookup/ getspatial?sir2014_5039_UCRBAgriculture.

\section{References Cited}

Chander, G., Markham, B.L., and Helder, D.L., 2009, Summary of current radiometric calibration coefficients for Landsat MSS, TM, ETM+, and EO-1 ALI sensors: Remote Sensing of Environment, v. 113, no. 5, p. 893-903.

Chavez, P.S., Jr., Sides, S.C., and Anderson, J.A., 1991, Comparison of three different methods to merge multiresolution and multispectral data-Landsat TM and SPOT Panchromatic: Photogrammetric Engineering and Remote Sensing, v. 57 , no. 3 , p. $295-303$. 
Congalton, R.G., Balogh, M., Bell, C., Green, K., Milliken, J.A., and Ottman, R., 1998, Mapping and monitoring agricultural crops and other land cover in the Lower Colorado River Basin: Photogrammetric Engineering and Remote Sensing, v. 64, no. 11, p. 1107-1113.

Congalton, R.G., and Green, K., 2009, Assessing the accuracy of remotely sensed data, principles and practices (2nd ed.): Boca Raton, Fla., CRC Press, 183 p.

Eckhart, D.W., Verdin, J.P., and Lyford, G.R., 1990, Automated update of an irrigated lands GIS using SPOT HRV imagery: Photogrammetric Engineering and Remote Sensing, v. 56, no. 11 , p. 1515-1522.

EXELIS visual information systems, 2011, ENVI EX (version 4.8) [Computer Software]: Boulder Colorado, http://www.exelisvis.com/.

Federal Geographic Data Committee, 1998, Geospatial positioning accuracy standards, Part 3-National Standard for Spatial Data Accuracy: FGDC-STD-007.3-1998.

Geneletti, D., and Gorte, B.G.H., 2003, A method for objectoriented land cover classification combining Landsat TM data and aerial photographs: International Journal of Remote Sensing, v. 24, no. 6, p. 1273-1286.

Homer, C., Dewitz, J., Fry, J., Coan, M., Hossain, N., Larson, C., Herold, N., McKerrow, A., VanDriel, J.N., and Wickham, J., 2007, Completion of the 2001 National Land Cover Database for the Conterminous United States: Photogrammetric Engineering and Remote Sensing, v. 73, no. 4, p. 337-341.

Huang, C., Davis, L.S., and Townshend, J.R.G., 2002, An assessment of support vector machines for land cover classification: International Journal of Remote Sensing, v. 23, no. 4 , p. $725-749$.

Huete, A., Didian, K., Miura, T., and Rodriguez, E., 2002, Overview of the radiometric and biophysical performance of the MODIS vegetation indices: Remote Sensing of Environment, v. 83, p. 195-213.

Iorns, W.V., Hembree, C.H., and Oakland, G.L., 1965, Water resources of the Upper Colorado River Basin-Technical report: U.S. Geological Survey Professional Paper 441, $370 \mathrm{p}$.

Jones, H.G., and Vaughan, R.A., 2010, Remote sensing of vegetation-Principles, techniques, and applications: New York, Oxford University Press, 353 p.

Kenney, T.A., Gerner, S.J., Buto, S.G., and Spangler, L.E., 2009, Spatially referenced statistical assessment of dissolved-solids load sources and transport in streams of the Upper Colorado River Basin: U.S. Geological Survey Scientific Investigations Report 2009-5007, 50 p., http://pubs.usgs.gov/sir/2009/5007/.
Kenny, J.F., Barber, N.L., Hutson, S.S., Linsey, K.S., Lovelace, J.K., and Maupin, M.A., 2009, Estimated use of water in the United States in 2005: U.S. Geological Survey Circular 1344, 52 p., http://pubs.usgs.gov/circ/1344/.

Liebermann, T.D., Mueller, D.K., Kircher, J.E., and Choquette, A.F., 1989, Characteristics and trends of streamflow and dissolved solids in the Upper Colorado River Basin, Arizona, Colorado, New Mexico, Utah, and Wyoming: U.S. Geological Survey Water-Supply Paper 2358, 64 p.

Lillesand, T.M., Kiefer, R.W., and Chipman, J.W., 2008, Remote sensing and image interpretation (6th ed.): Hoboken, N.J., John Wiley \& Sons, 756 p.

Lo, T.H.C., 1986, Use of multitemporal spectral profiles in agricultural land-cover classification: Photogrammetric Engineering and Remote Sensing, v. 52, no. 4, p. 535-544.

Masoner, J.R., Mladinich, C.S., Konduris, A.M., and Smith, S.J., 2003, Comparison of irrigation water use estimates calculated from remotely sensed irrigated acres and state reported irrigated acres in the Lake Altus drainage basin, Oklahoma and Texas, 2000 growing season: U.S. Geological Survey Water-Resources Investigations Report 03-4155, 39 p., http://pubs.usgs.gov/wri/wri034155/.

Ozdogan, M., and Gutman, G., 2008, A new methodology to map irrigated areas using multi-temporal MODIS and ancillary data-An application example in the continental US: Remote Sensing of Environment, v. 112, no. 9, p. $3520-3537$.

PRISM Group, Oregon State University, 2007, PRISM climate group [Digital climate data]: Corvallis, Oreg., Oregon Climate Service.

Simley, J.D., and Carswell, W.J., Jr., 2009, The National Map-Hydrography: U.S. Geological Survey Fact Sheet 2009-3054, 4 p., http://pubs.usgs.gov/fs/2009/3054/. (Revised March 2010)

Story, M., and Congalton, R.G., 1986, Accuracy assessmentA user's perspective: Photogrammetric Engineering and Remote Sensing, v. 52, no. 3, p. 397-399.

U.S. Census Bureau, 2000, Cartographic boundary files-2000 States: http://www.census.gov/geo/maps-data/data/prev_ cartbndry_names.html.

U.S. Census Bureau, 2010, Cartographic boundary files-2010 places, county subdivisions and related areas: $h t t p: / / w w w$. census.gov/geo/maps-data/data/cbf/cbf_counties.html.

U.S. Department of Agriculture, 2007, 2007 Census of agriculture: Special study, Upper Colorado water resource region 14, HUC 6 level watersheds, http://www.agcensus.usda.gov/ Publications/2007/Online_Highlights/Watersheds/uc14.pdf. 
U.S. Department of Agriculture, 2009, National Agricultural Imagery Program (NAIP) Information Sheet: 2 p., http:// www.fsa.usda.gov/Internet/FSA_File/naip_2012_final.pdf.

U.S. Department of Agriculture, U.S. Geological Survey, and the Environmental Protection Agency, 2013, Watershed Boundary Dataset for HUC region 14: U.S. Geological Survey, http://nhd.usgs.gov/wbd.html.

U.S. Department of the Interior, 2003, Quality of waterColorado River Basin progress report no. 21: Bureau of Reclamation, $90 \mathrm{p}$.
U.S. Geological Survey, 2012, Landsat-A global land-imaging mission: U.S. Geological Survey Fact Sheet 2012-3072, 4 p., http://pubs.usgs.gov/fs/2012/3072/. (Revised May 30, 2013)

U.S. Geological Survey, 2002, The National Map-Elevation: U.S. Geological Survey Fact Sheet 106-02, 2 p., http://pubs.usgs.gov/fs/2002/0106/report.pdf.

Yu, Q., Gong, P., Clinton, N., Biging, G., Kelly, M., and Schirokauer, D., 2006, Object-based detailed vegetation classification with airborne high spatial resolution remote sensing imagery: Photogrammetric Engineering \& Remote Sensing, v. 72 , no. 7 , p. $799-811$.

\section{Appendix 1}

\begin{tabular}{|c|c|c|c|c|c|}
\hline \multirow{3}{*}{ Row } & \multicolumn{5}{|c|}{ Path 34} \\
\hline & \multicolumn{4}{|c|}{ Year } & \multirow{2}{*}{ Landsat scene identifier } \\
\hline & 2007 & 2008 & 2009 & 2010 & \\
\hline \multirow[t]{5}{*}{32} & - & - & - & $6 / 21 / 2010$ & LT50340322010172EDC00 \\
\hline & $7 / 15 / 2007$ & - & - & - & LT50340322007196PAC01 \\
\hline & $7 / 31 / 2007$ & - & - & - & LT50340322007212PAC01 \\
\hline & $8 / 16 / 2007$ & - & - & - & LT50340322007228PAC01 \\
\hline & - & - & $8 / 21 / 2009$ & - & LT50340322009233PAC01 \\
\hline \multirow[t]{6}{*}{33} & - & $6 / 15 / 2008$ & - & - & LT50340332008167PAC01 \\
\hline & - & - & - & $6 / 21 / 2010$ & LT50340332010172EDC00 \\
\hline & $7 / 15 / 2007$ & - & - & - & LT50340332007196PAC01 \\
\hline & $7 / 31 / 2007$ & - & - & - & LT50340332007212PAC01 \\
\hline & - & - & $8 / 5 / 2009$ & - & LT50340332009217PAC01 \\
\hline & - & - & $8 / 21 / 2009$ & - & LT50340332009233PAC01 \\
\hline \multirow[t]{6}{*}{34} & - & $6 / 15 / 2008$ & - & - & LT50340342008167PAC01 \\
\hline & - & - & - & $6 / 21 / 2010$ & LT50340342010172EDC00 \\
\hline & $7 / 15 / 2007$ & - & - & - & LT50340342007196PAC01 \\
\hline & $7 / 31 / 2007$ & - & - & - & LT50340342007212PAC01 \\
\hline & - & $8 / 2 / 2008$ & - & - & LT50340342008215PAC01 \\
\hline & - & - & $8 / 21 / 2009$ & - & LT50340342009233PAC02 \\
\hline \multirow[t]{6}{*}{35} & - & - & - & $6 / 5 / 2010$ & LT50340352010156PAC01 \\
\hline & $6 / 29 / 2007$ & - & - & - & LT50340352007180PAC01 \\
\hline & $7 / 15 / 2007$ & - & - & - & LT50340352007196PAC01 \\
\hline & - & $8 / 2 / 2008$ & - & - & LT50340352008215PAC01 \\
\hline & $8 / 16 / 2007$ & - & - & - & LT50340352007228PAC01 \\
\hline & - & - & $8 / 21 / 2009$ & - & LT50340352009233PAC02 \\
\hline
\end{tabular}




\section{Appendix A1-2}

\begin{tabular}{|c|c|c|c|c|c|}
\hline \multirow{3}{*}{ Row } & \multicolumn{5}{|c|}{ Path 35} \\
\hline & \multicolumn{4}{|c|}{ Year } & \multirow{2}{*}{ Landsat scene identifier } \\
\hline & 2007 & 2008 & 2009 & 2010 & \\
\hline \multirow[t]{5}{*}{31} & - & - & - & $6 / 28 / 2010$ & LT50350312010179EDC00 \\
\hline & $7 / 6 / 2007$ & - & - & - & LT50350312007187PAC01 \\
\hline & $7 / 22 / 2007$ & - & - & - & LT50350312007203PAC01 \\
\hline & - & - & - & $8 / 15 / 2010$ & LT50350312010227EDC00 \\
\hline & - & - & $8 / 28 / 2009$ & - & LT50350312009240PAC02 \\
\hline \multirow[t]{5}{*}{32} & - & - & - & $6 / 28 / 2010$ & LT50350322010179EDC00 \\
\hline & $7 / 22 / 2007$ & - & - & - & LT50350322007203PAC01 \\
\hline & - & $7 / 24 / 2008$ & - & - & LT50350322008206PAC01 \\
\hline & - & - & - & $8 / 15 / 2010$ & LT50350322010227EDC00 \\
\hline & - & $8 / 25 / 2008$ & - & - & LT50350322008238PAC01 \\
\hline \multirow[t]{6}{*}{33} & $6 / 20 / 2007$ & - & - & - & LT50350332007171PAC01 \\
\hline & - & - & - & $6 / 28 / 2010$ & LT50350332010179EDC00 \\
\hline & - & $7 / 8 / 2008$ & - & - & LT50350332008190PAC01 \\
\hline & $7 / 22 / 2007$ & - & - & - & LT50350332007203PAC01 \\
\hline & - & - & - & $8 / 15 / 2010$ & LT50350332010227EDC00 \\
\hline & - & - & $8 / 28 / 2009$ & - & LT50350332009240PAC02 \\
\hline \multirow[t]{6}{*}{34} & - & $6 / 6 / 2008$ & - & - & LT50350342008158PAC01 \\
\hline & $6 / 20 / 2007$ & - & - & - & LT50350342007171PAC01 \\
\hline & - & - & $7 / 8 / 2008$ & - & LT50350342008190PAC01 \\
\hline & - & - & - & $7 / 27 / 2009$ & LT50350342009208PAC01 \\
\hline & - & - & $8 / 28 / 2009$ & - & LT50350342009240PAC02 \\
\hline & - & - & - & $9 / 16 / 2010$ & LT50350342010259PAC02 \\
\hline \multirow[t]{6}{*}{35} & - & $6 / 6 / 2008$ & - & - & LT50350352008158PAC01 \\
\hline & $6 / 20 / 2007$ & - & - & - & LT50350352007171PAC01 \\
\hline & - & - & $7 / 11 / 2009$ & - & LT50350352009192PAC01 \\
\hline & - & - & $7 / 27 / 2009$ & - & LT50350352009208PAC01 \\
\hline & - & $8 / 9 / 2008$ & - & - & LT50350352008222PAC01 \\
\hline & - & - & $8 / 28 / 2009$ & - & LT50350352009240PAC02 \\
\hline
\end{tabular}




\section{Appendix A1-3}

\begin{tabular}{|c|c|c|c|c|c|}
\hline \multirow{3}{*}{ Row } & \multicolumn{5}{|c|}{ Path 36} \\
\hline & \multicolumn{4}{|c|}{ Year } & \multirow{2}{*}{ Landsat scene identifier } \\
\hline & 2007 & 2008 & 2009 & 2010 & \\
\hline \multirow[t]{6}{*}{31} & - & - & - & $6 / 19 / 2010$ & LT50360312010170PAC01 \\
\hline & - & $6 / 29 / 2008$ & - & - & LT50360312008181PAC01 \\
\hline & - & $7 / 15 / 2008$ & - & - & LT50360312008197PAC01 \\
\hline & - & $7 / 31 / 2008$ & - & - & LT50360312008213PAC01 \\
\hline & - & - & $8 / 19 / 2009$ & - & LT50360312009231PAC01 \\
\hline & $8 / 30 / 2007$ & - & - & - & LT50360312007242PAC01 \\
\hline \multirow[t]{6}{*}{32} & - & - & - & $6 / 19 / 2010$ & LT50360322010170PAC01 \\
\hline & - & $6 / 29 / 2008$ & - & - & LT50360322008181PAC01 \\
\hline & - & $7 / 15 / 2008$ & - & - & LT50360322008197PAC01 \\
\hline & - & $7 / 31 / 2008$ & - & - & LT50360322008213PAC01 \\
\hline & - & - & $8 / 19 / 2009$ & - & LT50360322009231PAC01 \\
\hline & - & - & - & $9 / 7 / 2010$ & LT50360322010250PAC01 \\
\hline \multirow[t]{6}{*}{33} & - & - & - & $6 / 19 / 2010$ & LT50360332010170PAC01 \\
\hline & - & $6 / 29 / 2008$ & - & - & LT50360332008181PAC01 \\
\hline & - & $7 / 15 / 2008$ & - & - & LT50360332008197PAC01 \\
\hline & - & $7 / 31 / 2008$ & - & - & LT50360332008213PAC01 \\
\hline & - & - & $8 / 19 / 2009$ & - & LT50360332009231PAC01 \\
\hline & $8 / 30 / 2007$ & - & - & - & LT50360332007242PAC01 \\
\hline \multirow[t]{6}{*}{34} & - & - & - & $6 / 19 / 2010$ & LT50360342010170PAC01 \\
\hline & $6 / 27 / 2007$ & - & - & - & LT50360342007178PAC01 \\
\hline & - & - & - & $7 / 18 / 2009$ & LT50360342009199PAC01 \\
\hline & - & - & $7 / 31 / 2008$ & - & LT50360342008213PAC01 \\
\hline & - & - & $8 / 19 / 2009$ & - & LT50360342009231PAC01 \\
\hline & $8 / 30 / 2007$ & - & - & - & LT50360342007242PAC01 \\
\hline \multirow[t]{6}{*}{35} & - & - & - & $6 / 3 / 2010$ & LT50360352010154PAC01 \\
\hline & - & $6 / 29 / 2008$ & - & - & LT50360352008181PAC01 \\
\hline & $7 / 13 / 2007$ & - & - & - & LT50360352007194PAC01 \\
\hline & - & $7 / 31 / 2008$ & - & - & LT50360352008213PAC01 \\
\hline & - & - & $8 / 19 / 2009$ & - & LT50360352009231PAC01 \\
\hline & $8 / 30 / 2007$ & - & - & - & LT50360352007242PAC01 \\
\hline
\end{tabular}




\section{Appendix A1-4}

\begin{tabular}{|c|c|c|c|c|c|}
\hline \multirow{3}{*}{ Row } & \multicolumn{5}{|c|}{ Path 37} \\
\hline & \multicolumn{4}{|c|}{ Year } & \multirow{2}{*}{ Landsat scene identifier } \\
\hline & 2007 & 2008 & 2009 & 2010 & \\
\hline \multirow[t]{5}{*}{30} & $6 / 18 / 2007$ & - & - & - & LT50370302007169PAC01 \\
\hline & - & - & $6 / 23 / 2009$ & - & LT50370302009174EDC00 \\
\hline & - & - & $7 / 9 / 2009$ & - & LT50370302009190EDC00 \\
\hline & - & - & - & $8 / 13 / 2010$ & LT50370302010225PAC01 \\
\hline & - & - & $9 / 11 / 2009$ & - & LT50370302009254EDC00 \\
\hline \multirow[t]{5}{*}{31} & $6 / 18 / 2007$ & - & - & - & LT50370312007169PAC01 \\
\hline & - & - & $6 / 23 / 2009$ & - & LT50370312009174EDC00 \\
\hline & - & - & $7 / 9 / 2009$ & - & LT50370312009190EDC00 \\
\hline & - & - & $8 / 10 / 2009$ & - & LT50370312009222EDC00 \\
\hline & - & - & $8 / 26 / 2009$ & - & LT50370312009238EDC00 \\
\hline \multirow[t]{6}{*}{32} & $6 / 18 / 2007$ & - & - & - & LT50370322007169PAC01 \\
\hline & - & - & $6 / 23 / 2009$ & - & LT50370322009174EDC00 \\
\hline & $7 / 4 / 2007$ & - & - & - & LT50370322007185PAC01 \\
\hline & - & - & - & $7 / 12 / 2010$ & LT50370322010193EDC00 \\
\hline & - & - & $8 / 10 / 2009$ & - & LT50370322009222EDC00 \\
\hline & - & - & $8 / 26 / 2009$ & - & LT50370322009238EDC00 \\
\hline \multirow[t]{6}{*}{33} & $6 / 18 / 2007$ & - & - & - & LT50370332007169PAC01 \\
\hline & - & - & - & $6 / 26 / 2010$ & LT50370332010177PAC01 \\
\hline & $7 / 4 / 2007$ & - & - & - & LT50370332007185PAC01 \\
\hline & $7 / 20 / 2007$ & - & - & - & LT50370332007201PAC01 \\
\hline & - & - & - & $8 / 13 / 2010$ & LT50370332010225PAC01 \\
\hline & $8 / 21 / 2007$ & - & - & - & LT50370332007233PAC01 \\
\hline \multirow[t]{5}{*}{34} & - & $6 / 20 / 2008$ & - & - & LT50370342008172PAC01 \\
\hline & $7 / 4 / 2007$ & - & - & - & LT50370342007185PAC01 \\
\hline & - & - & - & $7 / 12 / 2010$ & LT50370342010193EDC00 \\
\hline & - & - & $8 / 10 / 2009$ & - & LT50370342009222EDC00 \\
\hline & - & $8 / 23 / 2008$ & - & - & LT50370342008236PAC01 \\
\hline \multirow[t]{4}{*}{35} & - & $6 / 20 / 2008$ & - & - & LT50370352008172PAC01 \\
\hline & - & - & $7 / 9 / 2009$ & - & LT50370352009190EDC00 \\
\hline & - & - & $8 / 10 / 2009$ & - & LT50370352009222EDC00 \\
\hline & - & $8 / 23 / 2008$ & - & - & LT50370352008236PAC01 \\
\hline
\end{tabular}



